\title{
A Study on the Mechanism and Kinetic of Nitrate Reduction by the nZVI-g-C3N4/TiO2 Composite Under the Simulated Sunlight
}

\section{Linyu Wei}

Sichuan Normal University

Jing Tian

Sichuan Normal University

Qing Wang

Sichuan Normal University

Yuanyuan Liu

Sichuan Normal University

Yi Yu

Sichuan Normal University

Chun Yang ( $\nabla$ chunyang@sicnu.edu.cn )

College of Chemistry and Materials Science, Sichuan Normal University, Chengdu 610066 https://orcid.org/0000-0001-7702-9715

\section{Research Article}

Keywords: Nitrate reduction, Mechanism, $\mathrm{HCOOH}, \mathrm{nZVI-g-C3N4/TiO2} \mathrm{composite}$

Posted Date: February 12th, 2021

DOl: https://doi.org/10.21203/rs.3.rs-216615/v1

License: (9) This work is licensed under a Creative Commons Attribution 4.0 International License. Read Full License 


\section{A Study on the Mechanism and Kinetic of Nitrate Reduction by the $\mathrm{nZVI}-\mathrm{g}-\mathrm{C}_{3} \mathrm{~N}_{4} / \mathrm{TiO}_{2}$ composite under the simulated sunlight}

Linyu Wei, ${ }^{\mathrm{a}}$ Jing Tian, ${ }^{\mathrm{a}}$ Qing Wang, ${ }^{\text {a }}$ Yuanyuan Liu, ${ }^{\mathrm{a}}$ Yi Yu, ${ }^{\mathrm{a}}$ Chun Yang, ${ }^{\text {abc }}$

*Corresponding author.

${ }^{\text {a }}$ College of Chemistry and Materials Science, Sichuan Normal University, Chengdu 610066

${ }^{\mathrm{b}}$ Sichuan Engineering Laboratory of Livestock Manure Treatment and Recycling, Chengdu 140028001

${ }^{c}$ Visual Computing and Virtual Reality Key Laboratory of Sichuan Province, Sichuan Normal University, Chengdu 610068

E-mail address: chunyang@sicnu.edu.cn (Chun Yang)

\section{Abstract}

g- $\mathrm{C}_{3} \mathrm{~N}_{4} / \mathrm{TiO}_{2}$ composite has excellent photoelectric properties and is considered as a good carrier of nanoparticles. A novel composite of nZVI-g- $\mathrm{C}_{3} \mathrm{~N}_{4} / \mathrm{TiO}_{2}$ was successfully synthesized through in-situ growth nZVI on the surface of $\mathrm{g}-\mathrm{C}_{3} \mathrm{~N}_{4} / \mathrm{TiO}_{2}$ with liquid phase reduction method. The composite was characterized by TEM, XRD, EDS and evaluated its nitrate removal efficiency. The effects of composite dosage, solution initial $\mathrm{pH}$ and $\mathrm{HCOOH}$ concentration on nitrate reduction were investigated. The results showed that nitrate was rapidly reduced by nZVI-g- $\mathrm{C}_{3} \mathrm{~N}_{4} / \mathrm{TiO}_{2}$ composite. The dosage of $4 \mathrm{~g} / \mathrm{L}$ nZVI-g- $\mathrm{C}_{3} \mathrm{~N}_{4} / \mathrm{TiO}_{2}$ composite and $3.0 \mathrm{mM}$ of $\mathrm{HCOOH}$ concentration was more suitable for nitrate reduction. Solution initial $\mathrm{pH}$ had little impact on the nitrate reduction efficiency, but affected the proportion of the nitrate reduction 
products. The mechanism of nitrate reduction in the $\mathrm{nZVI-gC} \mathrm{N}_{4} / \mathrm{TiO}_{2} / \mathrm{HCOOH}-\mathrm{Xe}-\mathrm{lamp}$ system was proposed. The nZVI-gC $\mathrm{g}_{3} \mathrm{~N}_{4} / \mathrm{TiO}_{2}$ composite could be considered as a viable and promising technology for water pollution remediation.

Keywords: Nitrate reduction, Mechanism, $\mathrm{HCOOH}, \mathrm{nZVI-g}-\mathrm{C}_{3} \mathrm{~N}_{4} / \mathrm{TiO}_{2}$ composite

\section{Introduction}

Nitrate contamination in groundwater and surface water has become more and more serious due to wastewater discharges from industry, agriculture, aquaculture and domestic sewage. Nitrate pollution not only poses a serious threat to human health, such as methemoglobinemia and cancer etc., but also causes serious water deterioration such as eutrophication[1-3]. At present, the traditional nitrate treatment technologies such as ion exchange, reverse osmosis only concentrate nitrate aqueous. And biological denitrification have high operational requirement such as temperature[4]. Among them, the combination of zero-valent iron (ZVI) and photocatalyst is considered as a most promising method for nitrate degradation due to its convenience, high efficiency and low cost $[5,6]$.

ZVI is widely used for nitrate removal because of its strong reduction ability, high activity, non-toxic, relatively low cost and simple operation[7, 8]. It is reported that nano-ZVI(nZVI) has larger specific surface area and higher reactivity than micro-ZVI (mZVI), which makes it have higher practical application value in nitrate treatment[9]. However, the nitrate degradation efficiency of nZVI often decreases due to its aggregation and agglomeration[10]. Thus, to overcome this drawback of nZVI, the carrier as dispersant is concerned and investigated. For instance, Zhang et al.[11] report that nZVI is highly dispersed on the surface of exfoliated graphite to prevent from aggregation and agglomeration. Furthermore, some carriers with high electrode 
potential, such as activated carbon, graphite, rGO, can form micro galvanic cells with nZVI in solution to promote electron transfer, thus increasing nitrate removal efficiency. Luo et al. [12] report that electron is driven from nZVI to the activated carbon due to a relative potential difference to rapidly reduce nitrate. Pu et al. [13] also report that the efficiency of nitrate removal by promoting electron migration from nZVI surface to rGO surface is enhanced. Up to now, supported nZVI materials such as goethite[14], diatomite[15], chelating resin[16, 17], C[4, 18], active carbon[19], biochar[20], silicon[21], graphene[22] have been studied. But these carriers still exist the disadvantages of tedious preparation and high cost. Therefore, it is necessary to develop an easy-prepared, low-cost supportive matrix to effectively disperse nZVI, and to form micro-galvanic cells with nZVI increasing nitrate removal efficiency.

Photocatalysis can effectively degrade environmental pollutants and be thought as a viable and promising technology for water pollution remediation[23-27]. $\mathrm{g}_{-} \mathrm{C}_{3} \mathrm{~N}_{4} / \mathrm{TiO}_{2}$ as a semiconductor and a photocatalyst has attracted much attention owing to low cost, non-toxic nature, good stability and environment friendliness etc[28-30]. However, the practical application of g- $\mathrm{C}_{3} \mathrm{~N}_{4} / \mathrm{TiO}_{2}$ was limited due to easy combination of photo-electrons and holes. According to the previous studies, doping metals such as $\mathrm{Au}, \mathrm{Ag}$, Pt effectively could suppress the electrons and holes rapid recombination to improve their photocatalytic performance[23, 31-33]. For example, lv et al.[31] report that $\mathrm{g}-\mathrm{C}_{3} \mathrm{~N}_{4} / \mathrm{TiO}_{2} / \mathrm{CQDs} / \mathrm{Au}$ of $\mathrm{H}_{2}$ production rate is 1.8 times than that of g- $\mathrm{C}_{3} \mathrm{~N}_{4} / \mathrm{TiO}_{2}$. Geng[33] et al. prove that doping metal $\mathrm{Ag}$ in the $\mathrm{g}-\mathrm{C}_{3} \mathrm{~N}_{4} / \mathrm{TiO}_{2}$ composite could accelerate separation of photoelectrons and holes.

Therefore, we design that $\mathrm{g}_{-} \mathrm{C}_{3} \mathrm{~N}_{4} / \mathrm{TiO}_{2}$ as photocatalyst is used to support nZVI. On the one hand, nZVI as mediator effectively promote separation of photo-charge carriers to enhance nitrate 
reduction. And g- $\mathrm{C}_{3} \mathrm{~N}_{4} / \mathrm{TiO}_{2}$ as carrier could highly disperse nZVI so as to provide more reactive sites. On the other hand, micro-galvanic cells formed by $\mathrm{g}_{-} \mathrm{C}_{3} \mathrm{~N}_{4} / \mathrm{TiO}_{2}$ as cathode and $\mathrm{nZVI}$ as anode accelerate the transfer of electrons and the redox progress of nitrate[34, 35]. In this work, a novel nZVI-g- $\mathrm{C}_{3} \mathrm{~N}_{4} / \mathrm{TiO}_{2}$ composite was prepared by in-situ liquid-phase reduction method and was used to reduce nitrate from aqueous solution under 300W Xe-lamp. The effects of composite dose, solution initial $\mathrm{pH}$ and $\mathrm{HCOOH}$ concentration on nitrate reduction were investigated. The mechanism of nitrate reduction in the nZVI-g- $\mathrm{C}_{3} \mathrm{~N}_{4} / \mathrm{TiO}_{2} / \mathrm{HCOOH} / \mathrm{Xe}$-lamp system was proposed.

\section{Materials and methods}

\subsection{Synthesis of the nZVI-g- $\mathrm{C}_{3} \mathrm{~N}_{4} / \mathrm{TiO}_{2}$ composite}

Preparation of the $\mathbf{g}-\mathrm{C}_{3} \mathbf{N}_{4} / \mathrm{TiO}_{2}$ composite: A mixture of $0.0577 \mathrm{~g} \mathrm{TiO}, 2.8835 \mathrm{~g}$ melamine and $2.0588 \mathrm{~g}$ Urea was ground and placed in a crucible covered with aluminum foil before calcinated at $520{ }^{\circ} \mathrm{C}$ for $4 \mathrm{~h}$ with a heating rate of $10{ }^{\circ} \mathrm{C} / \mathrm{min}$ in a muffle furnace. After cooling to room temperature, the as-obtained $\mathrm{g}-\mathrm{C}_{3} \mathrm{~N}_{4} / \mathrm{TiO}_{2}$ composite was ground into powder and ultrasonic for $0.5 \mathrm{~h}$ in deionized water with the ratio of $1 \mathrm{~g}$ : $50 \mathrm{~mL}$, followed by filtration. The ultrasonic and filtration process was repeated totally four times for removing impurities. Then the g- $\mathrm{C}_{3} \mathrm{~N}_{4} / \mathrm{TiO}_{2}$ composite was dried by microwave and ground into powder.

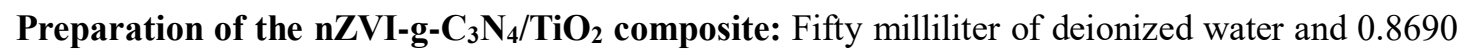
$\mathrm{g}$ anhydrous ferric chloride $\left(\mathrm{FeCl}_{3}\right)$ were stirred and mixed in a two-neck flask before $1 \mathrm{~g}$ of g- $\mathrm{C}_{3} \mathrm{~N}_{4} / \mathrm{TiO}_{2}$ composite added in. Then the mixture was treated with ultrasonic for $10 \mathrm{~min}$ followed by magnetic stirring for $3 \mathrm{~h}$. After that $80 \mathrm{~mL}$ of $0.2 \mathrm{M}$ sodium borohydride $\left(\mathrm{NaBH}_{4}\right)$ solution was quickly injected into the flask with syringe under vacuum condition. Then the mixture was thoroughly stirred for another 40 min under vacuum condition before filtration. The 
filter residue was washed with $15 \mathrm{~mL}$ de-ionized water and $15 \mathrm{~mL}$ anhydrous ethanol successively for three times before dried $60{ }^{\circ} \mathrm{C}$ for $12 \mathrm{~h}$ in vacuum oven. The as-obtained nZVI-g- $\mathrm{C}_{3} \mathrm{~N}_{4} / \mathrm{TiO}_{2}$ composite was then ground into powder ready for use. nZVI was also prepared following this procedure without g- $\mathrm{C}_{3} \mathrm{~N}_{4} / \mathrm{TiO}_{2}$ composite added.

\subsection{Characterization}

Transmission electron microscope (TEM, FEI Talos F200x and FEI Tecnai G2 F20) images and Energy Dispersive spectrometer (EDS, Oxford8118) spectrograms can investigate the morphology and the elementary content of nZVI-g- $\mathrm{C}_{3} \mathrm{~N}_{4} / \mathrm{TiO}_{2}$ composite. X-ray diffraction patterns (XRD, Bruker D8 ADVANCE A25X) were recorded in $5^{\circ}-85^{\circ}$ range.

\subsection{Nitrate reduction experiments}

The photo-induced nitrate reduction experiments were conducted by adding $\mathrm{XX} g$ as-prepared materials in to $50 \mathrm{~mL}$ nitrate solution with an initial concentration of $50 \mathrm{mg} \mathrm{N} / \mathrm{L}$. The initial $\mathrm{pH}$ of the nitrate solutions was adjusted to $2.0,2.5,3.6,7.0,8.0,9.0,10$, respectively, with $0.5 \mathrm{M} \mathrm{HCl} / \mathrm{NaOH}$. The suspensions were then irradiated by a $300 \mathrm{~W}$ Xe lamp. $3 \mathrm{~mL}$ sample solutions were taken every $10 \mathrm{~min}$ and then filtered with $0.22 \mu \mathrm{m}$ membrane. All samples were tested in a day. The concentrations of nitrate, ammonium, nitrite and $\mathrm{Fe}^{2+}$ in the filtrates were then determined by a UV-Vis spectrophotometer (SP-751, Jinghua, China) the wavelengths of $220 \mathrm{~nm}$, $420 \mathrm{~nm}, 540 \mathrm{~nm}$ and $510 \mathrm{~nm}$, respectively. After $\mathrm{Fe}^{3+}$ was reduced by hydroxylamine hydrochloride, the concentration of the total iron ions can be determined by analyzing $\mathrm{Fe}^{2+}$. All detection reagents were configured by the laboratory.

\subsection{Data analysis}

Nitrate removal efficiency, $\mathrm{X}_{\mathrm{NO}_{3}^{-}}$is calculated by Eq.1: 


$$
X_{\mathrm{NO}_{3}^{-}}=\frac{\left[\mathrm{NO}_{3}^{-}\right]_{0}-\left[\mathrm{NO}_{3}^{-}\right]_{t}}{\left[\mathrm{NO}_{3}^{-}\right]_{0}} \times 100 \%
$$

Where $\left[\mathrm{NO}_{3}^{-}\right]_{0}$ and $\left[\mathrm{NO}_{3}^{-}\right]_{t}$ are the concentration of nitrate nitrogen $(\mathrm{mg} \mathrm{N} / \mathrm{L})$ at time 0 and $\mathrm{t}$ (min), respectively. According to the reviewed research, nitrate nitrogen, ammonium nitrogen and nitrite nitrogen are thought as the main product of reduction because the content of the gas phase nitrous oxide $\left(N_{X} O\right)$ in the nitrate reduction process was negligible[14, 22, 36]. Thus, according to the mass balance of nitrogen, the nitrite selectivity $\left(S_{\mathrm{NO}_{2}^{-}}\right)$is calculated by Eq.2:

$$
S_{\mathrm{NO}_{2}^{-}}=\frac{\left[\mathrm{NO}_{2}^{-}\right]_{t}}{\left[\mathrm{NO}_{3}^{-}\right]_{0}-\left[\mathrm{NO}_{3}^{-}\right]_{t}} \times 100 \%
$$

$\mathrm{S}_{\mathrm{NH}_{4}^{+}}$was calculated by Eq.3:

$$
S_{\mathrm{NH}_{4}^{+}}=\frac{\left[\mathrm{NH}_{4}^{+}\right]_{t}}{\left[\mathrm{NO}_{3}^{-}\right]_{0}-\left[\mathrm{NO}_{3}^{-}\right]_{t}} \times 100 \%
$$

$S_{N_{2}}$ was calculated by Eq.4:

$$
S_{\mathrm{N}_{2}}=\frac{\left[\mathrm{NO}_{3}^{-}\right]_{0}-\left[\mathrm{NO}_{3}^{-}\right]_{t}-\left[\mathrm{NO}_{2}^{-}\right]_{t}-\left[\mathrm{NH}_{4}^{+}\right]_{t}}{\left[\mathrm{NO}_{3}^{-}\right]_{0}-\left[\mathrm{NO}_{3}^{-}\right]_{t}} \times 100 \%
$$

Where $\left[\mathrm{NO}_{2}^{-}\right]_{t}$ and $\left[\mathrm{NH}_{4}^{+}\right]_{t}$ are the concentration of nitrite nitrogen and ammonium nitrogen (mg N/L) at time t, respectively. Pseudo first-order dynamic model (Eq.5) is used to calculate the rate constant of nitrate reduction[5, 37, 38]. The rate constant of nitrate reduction was calculated as follows:

$$
\begin{aligned}
& \mathrm{r}=-\frac{d\left[\mathrm{NO}_{3}^{-}\right]_{t}}{d t}=k\left[\mathrm{NO}_{3}^{-}\right]_{t} \\
& \frac{d\left(\left[\mathrm{NO}_{3}^{-}\right]_{0}-\left[\mathrm{NO}_{3}^{-}\right]_{t}\right)}{\left[\mathrm{NO}_{3}^{-}\right]_{t}}=k d t \\
& \int_{0}^{\left(\left[\mathrm{NO}_{3}^{-}\right]_{0}-\left[\mathrm{NO}_{3}^{-}\right]_{t}\right)} \frac{d\left(\left[\mathrm{NO}_{3}^{-}\right]_{0}-\left[\mathrm{NO}_{3}^{-}\right]_{t}\right)}{\left[\mathrm{NO}_{3}^{-}\right]_{t}}=\int_{0}^{t} k d t \\
& \ln \frac{\left[\mathrm{NO}_{3}^{-}\right]_{0}}{\left[\mathrm{NO}_{3}^{-}\right]_{t}}=k t=\ln \frac{\mathrm{C}_{0}}{\mathrm{C}_{t}}
\end{aligned}
$$

Where $C_{0}$ and $C_{t}$ are the concentration of nitrate nitrogen $(\mathrm{mg} \mathrm{N} / \mathrm{L})$ at time 0 and $\mathrm{t}$. The rate constant of nitrate reduction is represented by $k$.

\section{Results and discussion}




\subsection{Characterization}

The X-Ray diffraction (XRD) patterns of the nZVI, TiO $, \quad g-\mathrm{C}_{3} \mathrm{~N}_{4}, g-\mathrm{C}_{3} \mathrm{~N}_{4} / \mathrm{TiO}_{2}$ and nZVI-g- $\mathrm{C}_{3} \mathrm{~N}_{4} / \mathrm{TiO}_{2}$ composite were shown in Figure. 1. Typical characteristic diffraction patterns of pure g- $\mathrm{C}_{3} \mathrm{~N}_{4}$ appeared at $27.2^{\circ}(2 \theta)$ and corresponded to $\left(\begin{array}{lll}0 & 0 & 2\end{array}\right)$ hexagonal crystal planes, which was consistent with the results in the literature[39]. The diffraction peaks of pure $\mathrm{TiO}_{2}$ appeared at $26.5^{\circ}, 37.3^{\circ}, 41.3^{\circ}, 54.4^{\circ}, 56.6^{\circ}$ and $62.8^{\circ}$, which corresponded to $\left(\begin{array}{lll}1 & 0 & 1\end{array}\right),\left(\begin{array}{lll}0 & 0 & 4\end{array}\right),\left(\begin{array}{lll}2 & 0 & 0\end{array}\right),\left(\begin{array}{lll}1 & 0 & 5\end{array}\right)$, (2 11 1), (2 $\left.\begin{array}{ll}2 & 4\end{array}\right)$ anatase phase of $\mathrm{TiO}_{2}$ crystal planes, respectively[36]. Compared with pure $\mathrm{TiO}_{2}$, peaks intensity of anatase $\mathrm{TiO}_{2}$ plane of thermal polymerization synthesis of $\mathrm{g}^{-} \mathrm{C}_{3} \mathrm{~N}_{4} / \mathrm{TiO}_{2}$ composite was weak because of the low content of $\mathrm{TiO}_{2}$. At the same time, the diffraction peak of g- $\mathrm{C}_{3} \mathrm{~N}_{4}$ moved a short distance after synthesizing g- $\mathrm{C}_{3} \mathrm{~N}_{4} / \mathrm{TiO}_{2}$ composite. For the XRD diffraction pattern of nZVI, the typical diffraction peak appeared at $44.8^{\circ}$ corresponds to $\alpha-\mathrm{Fe}\left(\begin{array}{lll}1 & 1 & 0\end{array}\right)$ crystal planes, which was consistent with the results in the literature[40, 41]. Otherwise, the typical characteristic diffraction peaks of $\mathrm{Fe}_{3} \mathrm{O}_{4}$ appeared at $35.5^{\circ}, 57.4^{\circ}$ and $62.9^{\circ}(2 \theta)$ corresponds to $\left(\begin{array}{lll}3 & 1 & 1\end{array}\right),\left(\begin{array}{lll}5 & 1 & 1\end{array}\right),\left(\begin{array}{lll}4 & 4 & 0\end{array}\right) \mathrm{Fe}_{3} \mathrm{O}_{4}$ crystal planes. The XRD diffraction pattern of nZVI-g- $\mathrm{C}_{3} \mathrm{~N}_{4} / \mathrm{TiO}_{2}$ composite revealed that the characteristic peaks of $\mathrm{g}_{-} \mathrm{C}_{3} \mathrm{~N}_{4}, \mathrm{nZVI}$ and $\mathrm{TiO}_{2}$ appeared at $27.2^{\circ}, 44.8^{\circ}$ and $54.4^{\circ}$ without other diffraction peaks of iron oxides. It suggested that g- $\mathrm{C}_{3} \mathrm{~N}_{4} / \mathrm{TiO}_{2}$ well immobilized and stabilized nZVI by a large number of $\pi$ electrons in the $\mathrm{g}-\mathrm{C}_{3} \mathrm{~N}_{4}$ composite,[22] which can inhibit and avoid the oxidation of nZVI in the preparation or storage process of nZVI-g- $\mathrm{C}_{3} \mathrm{~N}_{4} / \mathrm{TiO}_{2}$ composite. 


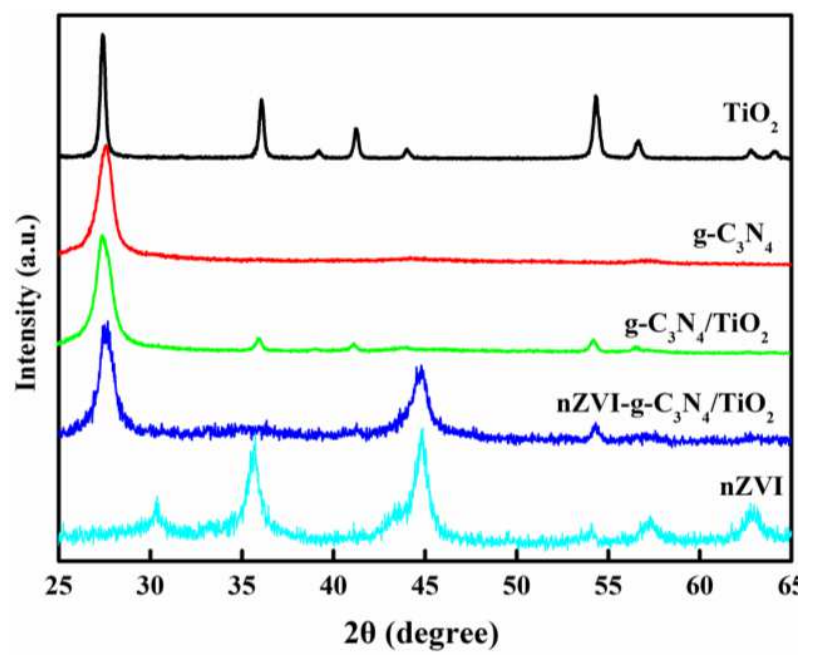

Fig.1 XRD patterns of nZVI, TiO $2, g-\mathrm{C}_{3} \mathrm{~N}_{4}, \mathrm{~g}-\mathrm{C}_{3} \mathrm{~N}_{4} / \mathrm{TiO}_{2}$ and nZVI-g- $\mathrm{C}_{3} \mathrm{~N}_{4} / \mathrm{TiO}_{2}$ composite.

Fig. 2a-c showed the morphological structure of $\mathrm{g}-\mathrm{C}_{3} \mathrm{~N}_{4} / \mathrm{TiO}_{2}, \quad \mathrm{nZVI}$ and nZVI-g- $\mathrm{C}_{3} \mathrm{~N}_{4} / \mathrm{TiO}_{2}$ composite using TEM. As shown in Fig. 2a, g- $\mathrm{C}_{3} \mathrm{~N}_{4} / \mathrm{TiO}_{2}$ composite was successfully synthesized. And it revealed that $\mathrm{TiO}_{2}$ was prominently distributed on the surface of the $\mathrm{g}-\mathrm{C}_{3} \mathrm{~N}_{4}$. At the same time, the $\mathrm{g}-\mathrm{C}_{3} \mathrm{~N}_{4}$ had the layered structure with wrinkles, which could provide abundant supporting sites for nZVI. As described in Fig. 2b, it revealed that nZVI had a chain-like structure and agglomerated. Compared with nZVI alone, nZVI particles supported on the surface of $\mathrm{g}-\mathrm{C}_{3} \mathrm{~N}_{4} / \mathrm{TiO}_{2}$ of diameter was shorter, which was observed from the TEM images (Fig. $2 b$ and c). Moreover, Fig. $2 \mathrm{c}$ showed that the nZVI was distributed well over the surface of the $\mathrm{g}_{-} \mathrm{C}_{3} \mathrm{~N}_{4} / \mathrm{TiO}_{2}$ composite due to in-situ reduction of $\mathrm{Fe}^{3+}$ by $\mathrm{NaBH}_{4}$ on the surface of $\mathrm{g}-\mathrm{C}_{3} \mathrm{~N}_{4} / \mathrm{TiO}_{2}$, which suggested that the $\mathrm{g}-\mathrm{C}_{3} \mathrm{~N}_{4} / \mathrm{TiO}_{2}$ composite was beneficial to the immobilization of nZVI, thereby inhibiting the aggregation and agglomeration of nZVI. EDS image (Fig. 2d) showed that nZVI-g- $\mathrm{C}_{3} \mathrm{~N}_{4} / \mathrm{TiO}_{2}$ composite mainly contains $\mathrm{C}, \mathrm{N}, \mathrm{O}$, Ti and Fe elements, and their mass fractions are $30.71 \%, 54.28 \%, 6.60 \%, 1.33 \%$ and $7.09 \%$, respectively. It confirmed that these elements coexisted in the nZVI-g- $\mathrm{C}_{3} \mathrm{~N}_{4} / \mathrm{TiO}_{2}$ composite. 

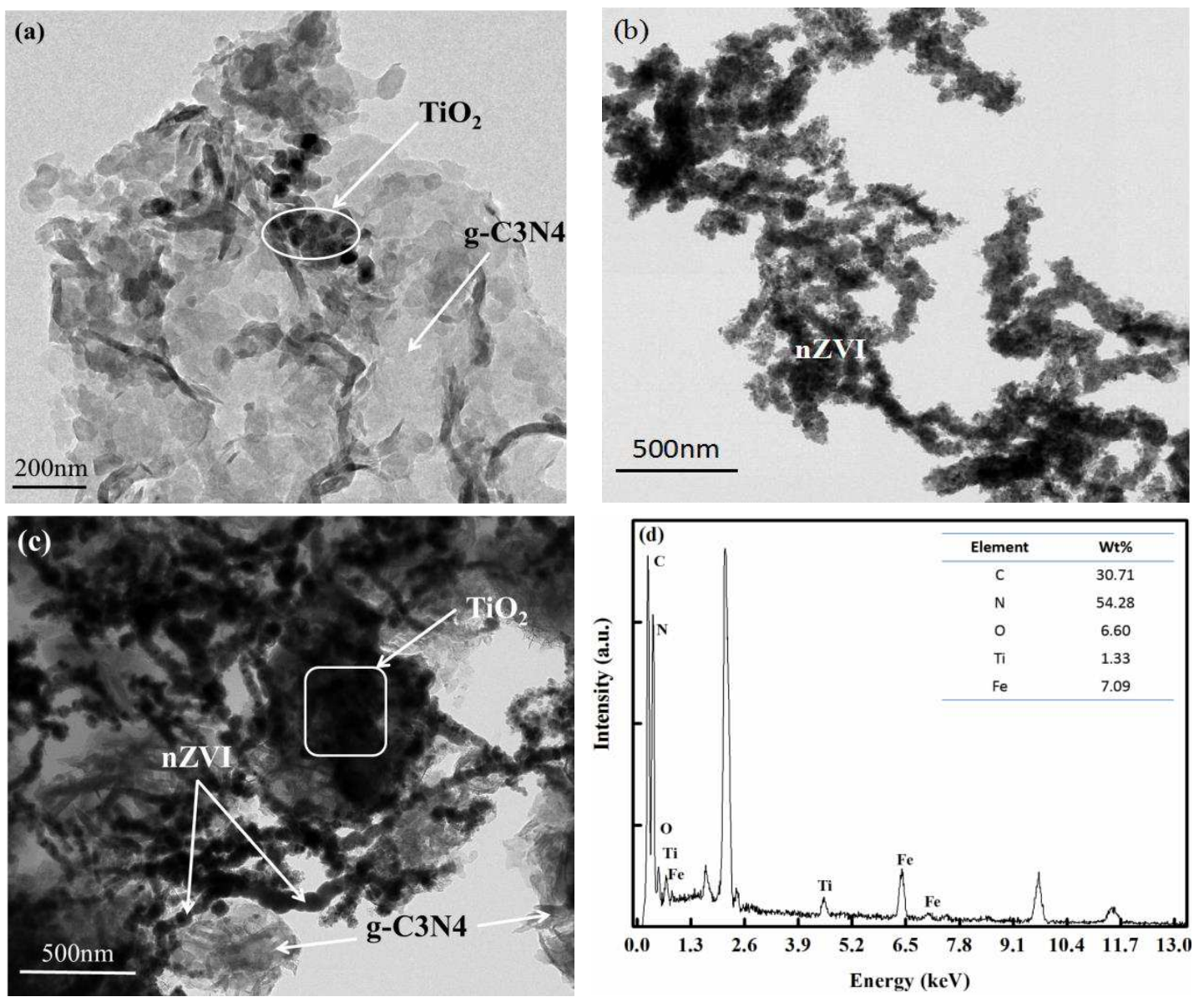

Fig. 2 TEM images for (a) the $\mathrm{g}-\mathrm{C}_{3} \mathrm{~N}_{4} / \mathrm{TiO}_{2}$; (b) the nZVI; (c) the nZVI-g- $\mathrm{C}_{3} \mathrm{~N}_{4} / \mathrm{TiO}_{2}$ composite;

(d) EDS spectrum of the nZVI-g- $\mathrm{C}_{3} \mathrm{~N}_{4} / \mathrm{TiO}_{2}$;

\subsection{Nitrate removal}
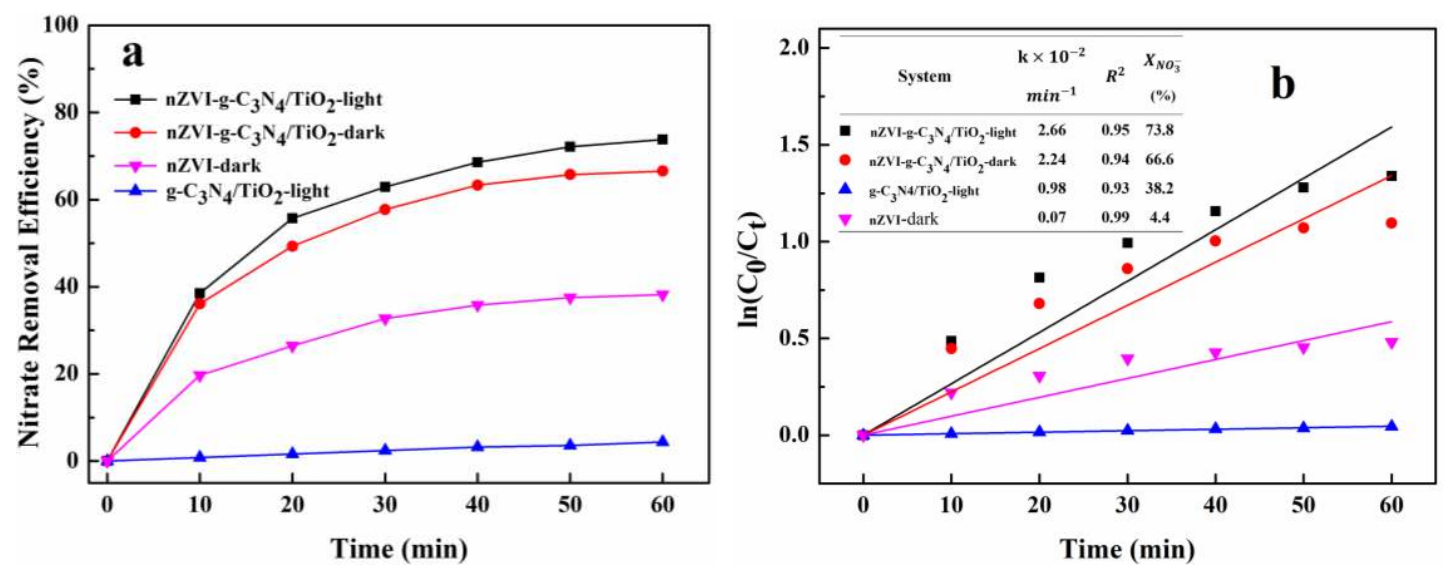

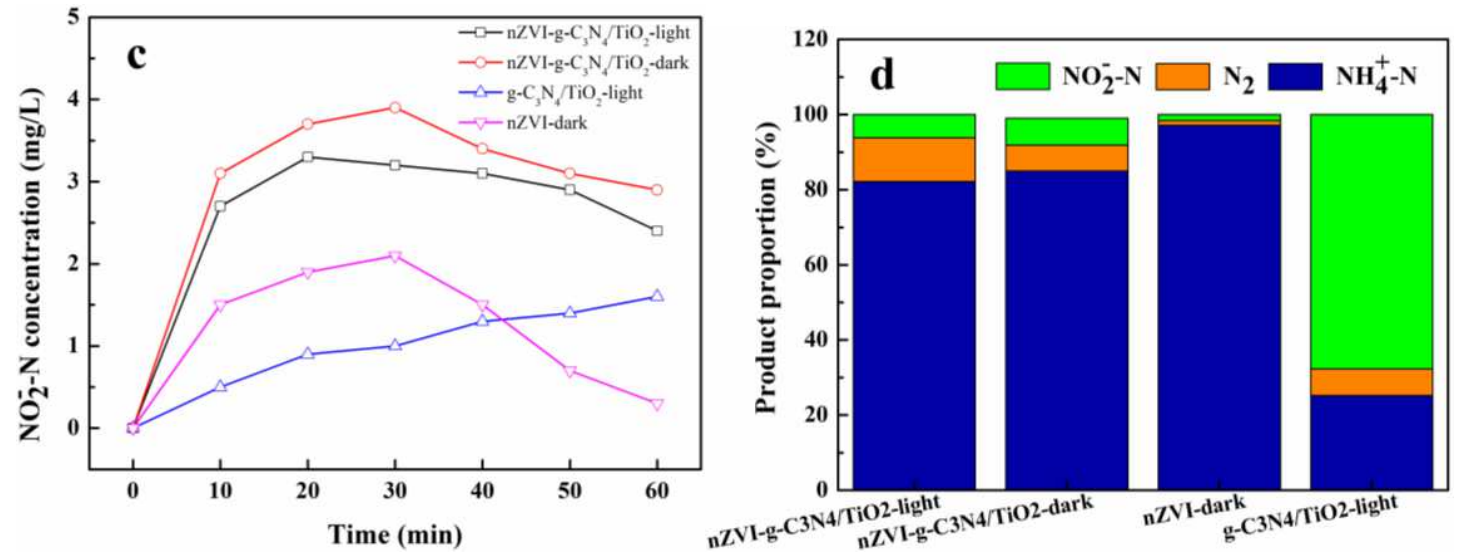

Fig. 3 (a) Nitrate removal efficiency of nZVI, g- $\mathrm{C}_{3} \mathrm{~N}_{4} / \mathrm{TiO}_{2}$ and nZVI-g- $\mathrm{C}_{3} \mathrm{~N}_{4} / \mathrm{TiO}_{2}$ composites; (b)

Rate constant of nitrate reduction in the different system; (c) nitrite nitrogen concentration $(\mathrm{mg} / \mathrm{L})$ changes during nitrate reduction; (d) Product proportion of nitrate reduction in the different system; (initial nitrate nitrogen concentration at $50 \mathrm{mg} / \mathrm{L}$; reductant dose at $4 \mathrm{~g} / \mathrm{L}$ and initial $\mathrm{pH}$ at 7.0)

As can be seen from Fig. 3a, the nitrate removal efficiency of nZVI-g- $\mathrm{C}_{3} \mathrm{~N}_{4} / \mathrm{TiO}_{2}$ composite (66.6\%) under the dark condition was higher than that of nZVI (38.2\%). Fig. 3b showed that the rate constant of nitrate reduction by $\mathrm{nZVI-g}-\mathrm{C}_{3} \mathrm{~N}_{4} / \mathrm{TiO}_{2}$ composite $\left(2.24 \times 10^{-2} \mathrm{~min}^{-1}\right)$ was 2.28 times than that of nZVI $\left(0.98 \times 10^{-2} \mathrm{~min}^{-1}\right)$, which suggested rapid nitrate reduction by nZVI-g- $\mathrm{C}_{3} \mathrm{~N}_{4} / \mathrm{TiO}_{2}$ composite, likely due to micro-galvanic cells formed by nZVI-g- $\mathrm{C}_{3} \mathrm{~N}_{4} / \mathrm{TiO}_{2}$ composite in the solution. It promoted electron release of quickly from nZVI and transfer to nitrate for nitrate reduction. Moreover, this might also be because nZVI highly dispersed on the surface of $\mathrm{g}-\mathrm{C}_{3} \mathrm{~N}_{4} / \mathrm{TiO}_{2}$ could provide more active sites for nitrate reduction. Fig. $3 \mathrm{a}$ revealed that the order of nitrate removal efficiency was as: nZVI-g- $\mathrm{C}_{3} \mathrm{~N}_{4} / \mathrm{TiO}_{2}$-light $(73.8 \%)>\mathrm{g}-\mathrm{C}_{3} \mathrm{~N}_{4} / \mathrm{TiO}_{2}$-light (4.4\%), which suggested that $\mathrm{g}-\mathrm{C}_{3} \mathrm{~N}_{4} / \mathrm{TiO}_{2}$ under the light condition contributed to the poor nitrate removal. On the contrary, nitrate reduction efficiency by nZVI-g- $\mathrm{C}_{3} \mathrm{~N}_{4} / \mathrm{TiO}_{2}$ composite was obviously improved. This was because nZVI acting as electron mediator can facilitate the 
separation of photo-generated charge carriers. Then a amount of photo-generated electrons excited by the g $_{3} \mathrm{C}_{3} \mathrm{~N}_{4} / \mathrm{TiO}_{2}$ under Xe-lamp can promote nitrate reduction. In brief, nitrate reduction by nZVI-g- $\mathrm{C}_{3} \mathrm{~N}_{4} / \mathrm{TiO}_{2}$ composite was mainly due to the synergistic effect of micro-galvanic cells, followed by photocatalysis.

Fig. $3 \mathrm{c}$ indicated that for nitrate removal by $\mathrm{nZVI}$ alone, $\mathrm{NO}_{2}^{-}-\mathrm{N}$ accumulated in the initial reaction and then completely reduced to $\mathrm{N}_{2}$ or $\mathrm{NH}_{4}^{+}-\mathrm{N}$. For nitrate removal by $\mathrm{g}_{-} \mathrm{C}_{3} \mathrm{~N}_{4} / \mathrm{TiO}_{2}$, the concentration of $\mathrm{NO}_{2}^{-}-\mathrm{N}$ increased with time. Moreover, Fig. $4 \mathrm{~d}$ showed that the primary product nitrate removal by $\mathrm{g}_{-} \mathrm{C}_{3} \mathrm{~N}_{4} / \mathrm{TiO}_{2}$ was nitrite and its $\mathrm{NO}_{2}^{-}-\mathrm{N}$ selectivity was $67.7 \%$. However, For nitrate removal by nZVI-g- $\mathrm{C}_{3} \mathrm{~N}_{4} / \mathrm{TiO}_{2}$ composite, $\mathrm{NO}_{2}^{-}-\mathrm{N}$ as an intermediate product was accumulated whether in the dark or light condition, and then only a little reduced to $\mathrm{N}_{2}$ or $\mathrm{NH}_{4}^{+}-\mathrm{N}$. The reason was that $\mathrm{NO}_{2}^{-}-\mathrm{N}$ accumulated in the solution prior to electron migration to the surface of $\mathrm{g}-\mathrm{C}_{3} \mathrm{~N}_{4} / \mathrm{TiO}_{2}$ for further reduction. Meanwhile, Fig. $4 \mathrm{~d}$ revealed that the order of $N_{2}$ selectivity was as: nZVI-g-C $\mathrm{C}_{3} \mathrm{~N}_{4} / \mathrm{TiO}_{2}$-light (11.6\%) > g- $\mathrm{C}_{3} \mathrm{~N}_{4} / \mathrm{TiO}_{2}$-light $(7.1 \%)>$ nZVI-g- $\mathrm{C}_{3} \mathrm{~N}_{4} / \mathrm{TiO}_{2}$-dark $(6.9 \%)>$ nZVI-dark $(1.3 \%)$. This was because a standard potential of $1.45 \mathrm{~V}$ vs Standard Hydrogen Electrode (SHE) of nitrite reduced to $N_{2}$ is higher than that of nitrate $E^{\theta}\left(\mathrm{NO}_{3}^{-} / N_{2}=1.25 \mathrm{~V}\right)$. It suggested that the high nitrite nitrogen concentration in the solution was more conducive to $N_{2}$ than nitrate. Thus, $N_{2}$ selectivity of nitrate removal by nZVI-g- $\mathrm{C}_{3} \mathrm{~N}_{4} / \mathrm{TiO}_{2}$ composite was enhanced as the results shown in Fig. $4 \mathrm{~d}$.

\subsection{Effects of composite dosage on nitrate reduction}



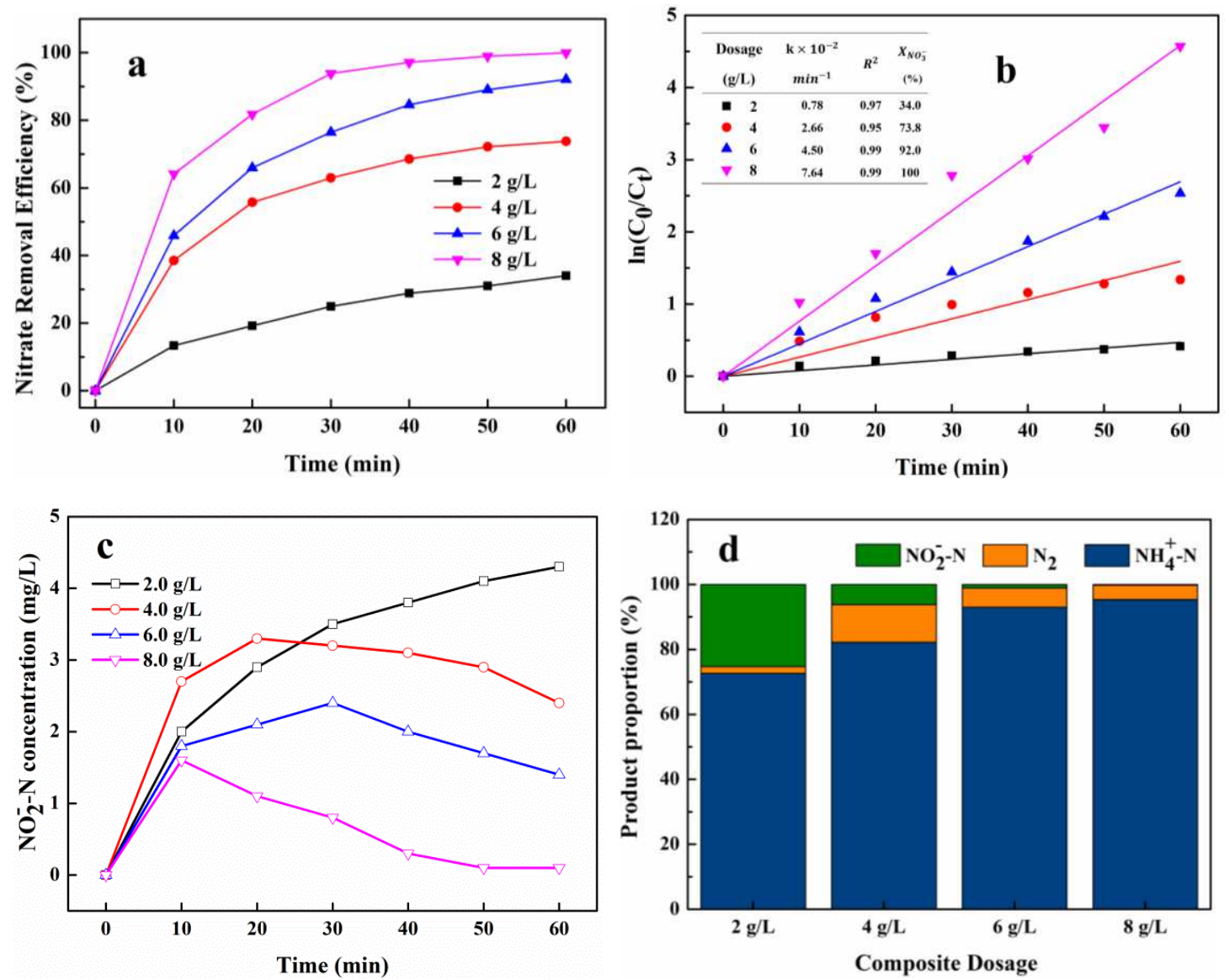

Fig. 4 (a) Nitrate removal efficiency in the different nZVI-g- $\mathrm{C}_{3} \mathrm{~N}_{4} / \mathrm{TiO}_{2}$ composite dosage;(b) Rate constant of nitrate reduction in the different composite dosage; (c) nitrite nitrogen concentration ( $\mathrm{mg} / \mathrm{L}$ ) changes during nitrate reduction; (d) Product proportion of nitrate reduction in the different composite dosage; ( initial nitrate nitrogen concentration at $50 \mathrm{mg} / \mathrm{L}$; initial $\mathrm{pH}$ at 7.0 )

As shown in Fig. 4a and b, nitrate reduction rate constant $k$ and nitrate removal efficiency $X_{\mathrm{NO}_{3}^{-}}$were both enhanced with the increase nZVI-g- $\mathrm{C}_{3} \mathrm{~N}_{4} / \mathrm{TiO}_{2}$ composite. $X_{\mathrm{NO}_{3}^{-}}$increased from $34 \%$ to $100 \%$ with the dosage increase from $2 \mathrm{~g} / \mathrm{L}$ to $8 \mathrm{~g} / \mathrm{L}$. And the $\mathrm{k}$ of $8 \mathrm{~g} / \mathrm{L}$ dosage was 9.8 times higher than of $2 \mathrm{~g} / \mathrm{L}$ dosage. The enhanced nitrate reduction was because higher dosage of nZVI-g- $\mathrm{C}_{3} \mathrm{~N}_{4} / \mathrm{TiO}_{2}$ composite provided more active sites to react with nitrate. Fig. $4 \mathrm{c}$ showed that except for dosage of $2 \mathrm{~g} / \mathrm{L}, \mathrm{NO}_{2}^{-}-\mathrm{N}$ concentration of other dosage accumulated at the beginning stage of reaction and then decreased. When the dosage was $8 \mathrm{~g} / \mathrm{L}$, nitrite nitrogen was completely 
reduced. The reason was that excess composite dosage could provide sufficient active sites. Noticeably, $\mathrm{NO}_{2}^{-}-\mathrm{N}$ concentration of nitrate removal by $2 \mathrm{~g} / \mathrm{L}$ dosage increased with time. And Fig. 4d indicated that its $\mathrm{NO}_{2}^{-}-\mathrm{N}$ selectivity was higher others, which might be because that the low dosage of nZVI-g- $\mathrm{C}_{3} \mathrm{~N}_{4} / \mathrm{TiO}_{2}$ composite provide insufficient electron for nitrate reduction, thus resulting in nitrite accumulation.

\subsection{Effects of initial pH on nitrate reduction}
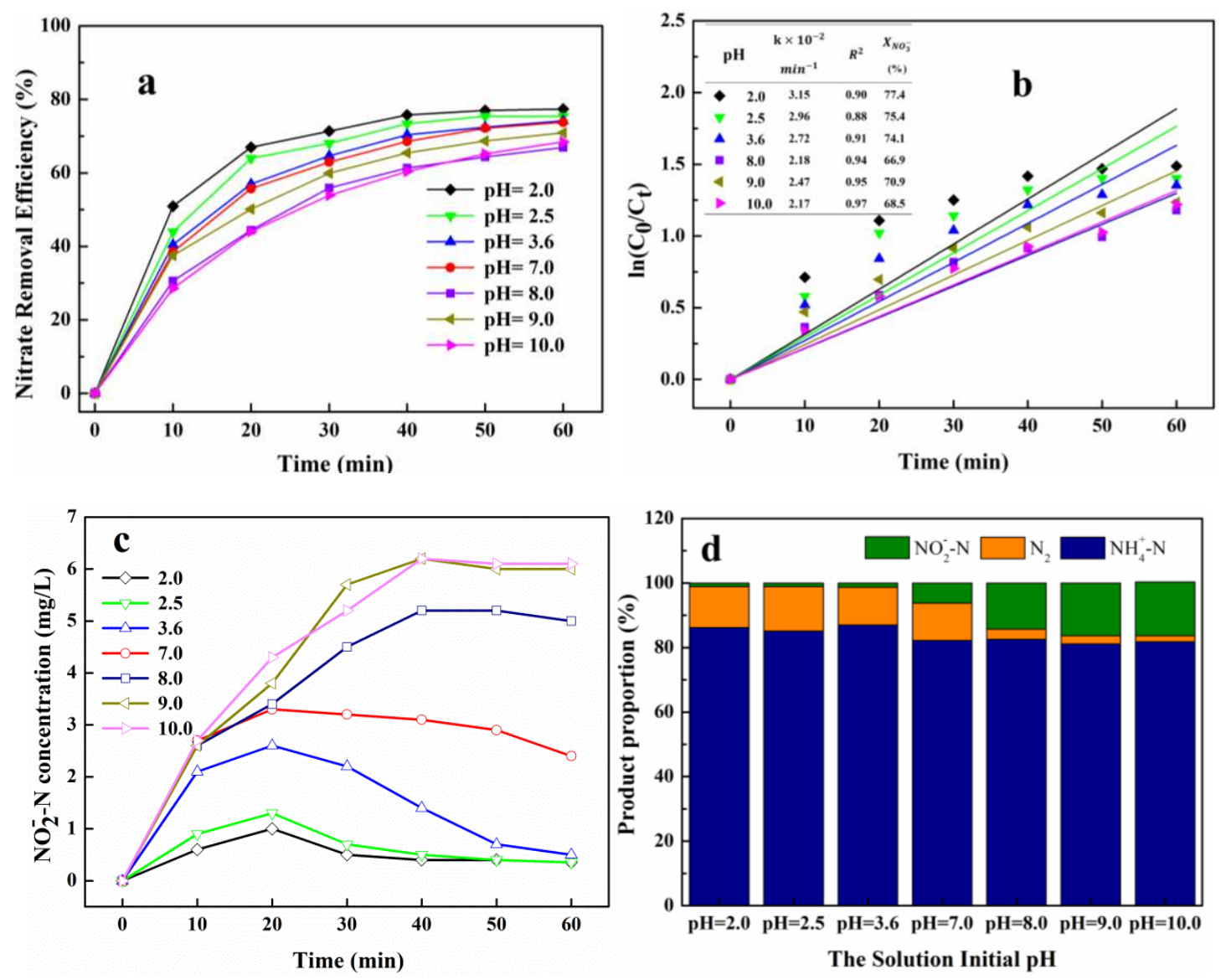

Fig. 5 (a) Nitrate removal efficiency in the different solution initial pH; (b) Rate constant of nitrate reduction in the different Initial $\mathrm{pH}$ of solution; (c) nitrite nitrogen concentration $(\mathrm{mg} / \mathrm{L})$ changes during nitrate reduction; (d) Product proportion of nitrate reduction in the different Initial $\mathrm{pH}$ of solution; ( initial nitrate nitrogen concentration at $50 \mathrm{mg} / \mathrm{L}$; reductant dose at $4 \mathrm{~g} / \mathrm{L}$ )

Fig. 5a and $\mathrm{b}$ indicated that the nitrate removal efficiency slightly increased as the solution 
$\mathrm{pH}$ decreasing from 7.0 to 2.0 , and the rate constant slightly increased from $2.66 \times 10^{-2} \mathrm{~min}^{-1}$ to $3.15 \times 10^{-2} \mathrm{~min}^{-1}$. This was because a part of $\mathrm{H}^{+}$occupied active sites on the surface of g- $\mathrm{C}_{3} \mathrm{~N}_{4} / \mathrm{TiO}_{2}$ because of electrostatic attraction. Fig. $5 \mathrm{c}$ revealed that $\mathrm{NO}_{2}^{-}-\mathrm{N}$ concentration was accumulated firstly, and then reduced to $\mathrm{NH}_{4}^{+}-\mathrm{N}$ or $\mathrm{N}_{2}$. Moreover, Fig. $5 \mathrm{~d}$ also showed that the $\mathrm{NO}_{2}^{-}-\mathrm{N}$ selectivity decreased from $6.2 \%$ to $1.1 \%$ with the decreasing solution initial $\mathrm{pH}$ from 7.0 to 2.0. However, at the alkaline condition, Fig. $5 \mathrm{c}$ showed that $\mathrm{NO}_{2}^{-}-\mathrm{N}$ concentration continuously increased with time. And Fig. $5 \mathrm{c}$ also showed that its $\mathrm{NO}_{2}^{-}-\mathrm{N}$ selectivity obviously increased. The reason might be that the high concentration of $\mathrm{OH}^{-}$suppressed the reduction of $\mathrm{NO}_{2}^{-}-\mathrm{N}$. The nitrate removal efficiency $\mathrm{X}_{\mathrm{NO}_{3}^{-}}$and rate constant k slightly decreased. This result might be related to the surface charge of nZVI-g- $\mathrm{C}_{3} \mathrm{~N}_{4} / \mathrm{TiO}_{2}$ composite. In brief, changing initial $\mathrm{pH}$ mainly affected product proportion of nitrate product.

\subsection{Nitrate reduction mechanism of $\mathrm{nZVI}-\mathrm{gC}_{3} \mathrm{~N}_{4} / \mathrm{TiO}_{2} / \mathrm{HCOOH} / \mathrm{Xe}-\mathrm{lamp}$}
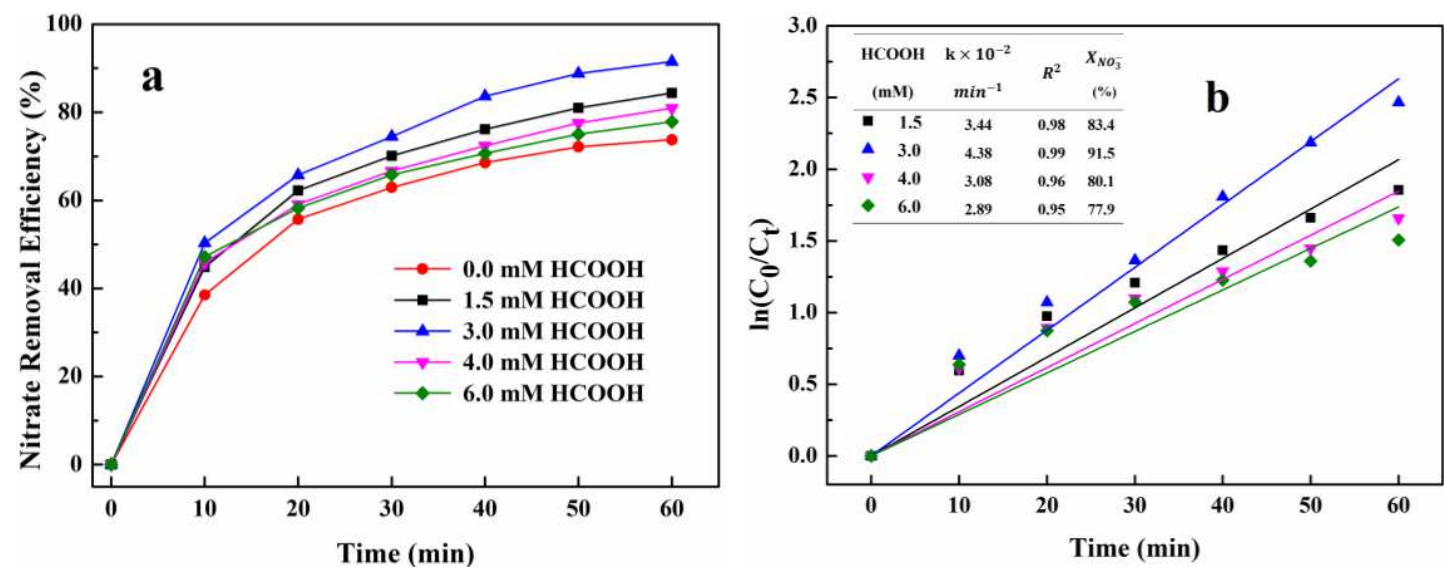

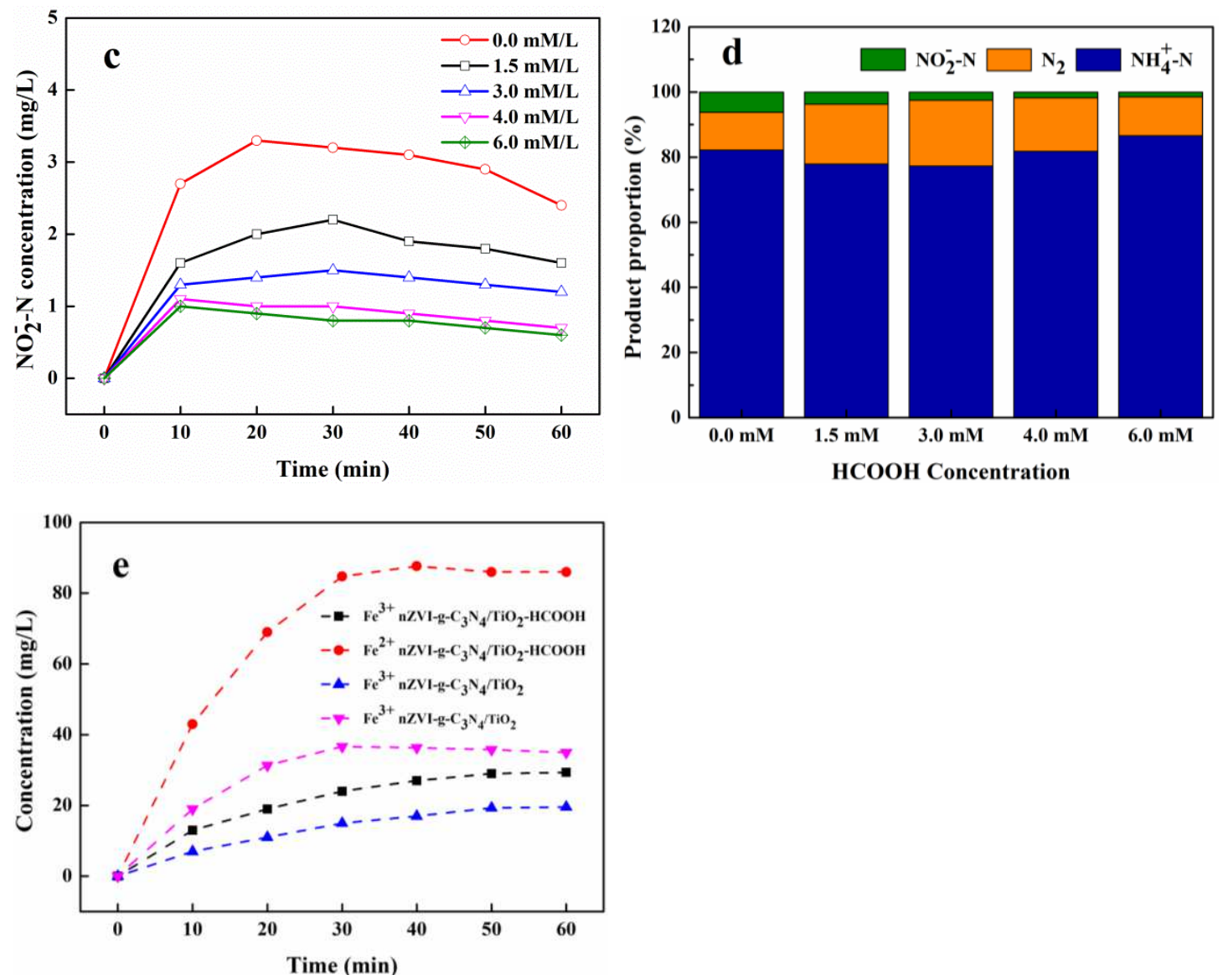

Fig. 6 (a) Nitrate removal efficiency in the different $\mathrm{HCOOH}$ concentration; (b) Rate constant of nitrate reduction in the different Initial $\mathrm{pH}$ of solution; (c) nitrite nitrogen concentration (mg/L) changes during nitrate reduction; (d) Product proportion of nitrate reduction in the different Initial $\mathrm{pH}$ of solution; (e) and the concentration of $\mathrm{Fe}^{2+}$ and $\mathrm{Fe}^{3+}$ with time; ( initial nitrate nitrogen concentration at $50 \mathrm{mg} / \mathrm{L}$; reductant dose at $4 \mathrm{~g} / \mathrm{L}$ )

$\mathrm{HCOOH}$ is widely used as a hole scavenger for nitrate reduction based on the single electron transfer mechanism and forming a strong reductant species $\mathrm{CO}_{2}^{--}$as the only product [36, 42]. Moreover, the strong reductant species $\mathrm{CO}_{2}^{--}\left(E^{\theta}\left(\mathrm{CO}_{2} / \mathrm{CO}_{2}^{--}\right)=-1.8 \mathrm{~V}\right)$, which was produced by the reaction between $\mathrm{HCOOH}$ and the photo-generated hole excited by $\mathrm{g}-\mathrm{C}_{3} \mathrm{~N}_{4} / \mathrm{TiO}_{2}$ composite under the Xe-lamp, can reduce nitrate nitrogen to ammonium nitrogen $\left(\mathrm{E}^{\theta}\left(\mathrm{NO}_{3}^{-} / \mathrm{NH}_{4}^{+}\right)=\right.$ 1.203), nitrite nitrogen $\left(E^{\theta}\left(\mathrm{NO}_{3}^{-} / \mathrm{NO}_{2}^{-}\right)=0.94 \mathrm{~V}\right)$ and nitrogen gas $\left(E^{\theta}\left(\mathrm{NO}_{3}^{-} / \mathrm{N}_{2}\right)=1.25 \mathrm{~V}\right)$. 
As depicted in Fig. 6a and b, the nitrate removal efficiency $\left(\mathrm{X}_{\mathrm{NO}_{3}^{-}}\right)$and the rate constant $\mathrm{k}$ increased after adding $\mathrm{HCOOH}$. The $\mathrm{X}_{\mathrm{NO}_{3}^{-}}$increased from $73.8 \%$ to $91.5 \%$ when $\mathrm{HCOOH}$ concentration increased from 0 to $3.0 \mathrm{mM}$. The $\mathrm{k}$ increased from $2.66 \times 10^{-2} \mathrm{~min}^{-1}$ to $4.26 \times$ $10^{-2} \mathrm{~min}^{-1}$. It suggested that adding $\mathrm{HCOOH}$ in the reaction system was conducive to nitrate reduction rate and efficiency. Noticeably, the nitrate removal efficiency decreased when $\mathrm{HCOOH}$ concentration increased from $3.0 \mathrm{mM}$ to $6.0 \mathrm{mM}$, and the $\mathrm{k}$ also decreased from $4.26 \times$ $10^{-2} \mathrm{~min}^{-1}$ to $2.94 \times 10^{-2} \mathrm{~min}^{-1}$. This was because that the active sites on the surface of nZVI-g- $\mathrm{C}_{3} \mathrm{~N}_{4} / \mathrm{TiO}_{2}$ composite might be occupied by excessive $\mathrm{HCOOH}$. As depicted in Fig. 6c, only a little $\mathrm{NO}_{2}^{-}-\mathrm{N}$ remained in the solution aqueous. At the same time, as can be seen from Fig. $6 \mathrm{~d}, \mathrm{NO}_{2}^{-}-\mathrm{N}$ selectivity decreased as the increasing $\mathrm{HCOOH}$ concentration. In addition, $N_{2}$ selectivity was enhanced. Especially, when the concentration of $\mathrm{HCOOH}$ was $3.0 \mathrm{mM}$, its $N_{2}$ selectivity was $20.2 \%$. But Fig. 6 d revealed that nitrate nitrogen was mainly reduced to ammonium nitrogen. Therefore, the related reaction was described as followed:

$$
\begin{gathered}
\mathrm{g}-\mathrm{C}_{3} \mathrm{~N}_{4} / \mathrm{TiO}_{2}+\mathrm{hv} \rightarrow \mathrm{h}^{+}+e^{-} \\
\mathrm{HCOOH}+h_{v b}^{+} \rightarrow 2 \mathrm{H}^{+}+\mathrm{CO}_{2}^{--} \\
\mathrm{NO}_{3}^{-}+10 \mathrm{H}^{+}+8 \mathrm{CO}_{2}^{--} \rightarrow \mathrm{NH}_{4}^{+}+3 \mathrm{H}_{2} \mathrm{O}+8 \mathrm{CO}_{2} \\
\mathrm{NO}_{3}^{-}+2 \mathrm{H}^{+}+2 \mathrm{CO}_{2}^{--} \rightarrow \mathrm{NO}_{2}^{-}+\mathrm{H}_{2} \mathrm{O}+2 \mathrm{CO}_{2} \\
2 \mathrm{NO}_{3}^{-}+12 \mathrm{H}^{+}+10 \mathrm{CO}_{2}^{--} \rightarrow \mathrm{N}_{2}+6 \mathrm{H}_{2} \mathrm{O}+10 \mathrm{CO}_{2}
\end{gathered}
$$

In addition, a lot of photo-generated electron produced by the excitation of $g-\mathrm{C}_{3} \mathrm{~N}_{4} / \mathrm{TiO}_{2}$ under the Xe-lamp could reduce nitrate. Meanwhile, electrons from the micro-galvanic cells formed by nZVI as anode and $\mathrm{g}^{-} \mathrm{C}_{3} \mathrm{~N}_{4} / \mathrm{TiO}_{2}$ as cathode in the solution aqueous also can promote nitrate reduction. And Fig. 6e indicated that nZVI after releasing electrons was mainly oxidized to 
ferrous ions in the solution aqueous. Especially, the concentration of ferrous ions at the $\mathrm{HCOOH}$ condition was far higher than no $\mathrm{HCOOH}$. This might be because $\mathrm{Fe}^{3+}$ was reduced by the strong reductant species $\mathrm{CO}_{2}^{--}$. In the Section 3.2, it proved that $\mathrm{NO}_{3}^{-}-\mathrm{N}$ was rapidly reduced to $\mathrm{NH}_{4}^{+}-\mathrm{N}, \mathrm{NO}_{2}^{-}-\mathrm{N}$ and $\mathrm{N}_{2}$ due to micro-galvanic cells formed by nZVI as anode and g- $\mathrm{C}_{3} \mathrm{~N}_{4} / \mathrm{TiO}_{2}$ as cathode. Therefore, the related actions can be described as follows:

$\mathrm{Fe}^{0}$ anode (oxidation):

$$
F e_{(s)} \rightarrow F e_{(a q)}^{2+}+2 e^{-}
$$

g- $\mathrm{C}_{3} \mathrm{~N}_{4} / \mathrm{TiO}_{2}$ cathode (reduction):

$$
\begin{gathered}
\mathrm{NO}_{3}^{-}+10 \mathrm{H}^{+}+8 e^{-} \rightarrow \mathrm{NH}_{4}^{+}+3 \mathrm{H}_{2} \mathrm{O} \\
\mathrm{NO}_{3}^{-}+2 \mathrm{H}^{+}+2 e^{-} \rightarrow \mathrm{NO}_{2}^{-}+\mathrm{H}_{2} \mathrm{O} \\
2 \mathrm{NO}_{3}^{-}+12 \mathrm{H}^{+}+10 e^{-} \rightarrow \mathrm{N}_{2}+3 \mathrm{H}_{2} \mathrm{O}
\end{gathered}
$$

Thus, the nitrate nitrogen in the $\mathrm{nZVI}-\mathrm{g}-\mathrm{C}_{3} \mathrm{~N}_{4} / \mathrm{TiO}_{2}-\mathrm{HCOOH}$ system was rapidly reduced to $\mathrm{NH}_{4}^{+}-\mathrm{N}, \mathrm{NO}_{2}^{-}-\mathrm{N}$ and $\mathrm{N}_{2}$ due to the synergistic effects of the micro-galvanic cells formed by nZVI as anode and g- $\mathrm{C}_{3} \mathrm{~N}_{4} / \mathrm{TiO}_{2}$ as cathode, the photo-generated electrons excited by $\mathrm{g}-\mathrm{C}_{3} \mathrm{~N}_{4} / \mathrm{TiO}_{2}$ under the Xe-lamp and a $\mathrm{CO}_{2}^{--}$species, which was produced by the reaction of the $\mathrm{HCOOH}$ and the photo-generated holes excited by $g-\mathrm{C}_{3} \mathrm{~N}_{4} / \mathrm{TiO}_{2}$ under the Xe-lamp. In order to clearly understand the mechanism of nitrate reduction in the $\mathrm{nZVI}-\mathrm{gC}_{3} \mathrm{~N}_{4} / \mathrm{TiO}_{2} / \mathrm{HCOOH} / \mathrm{Xe}-\mathrm{lamp}$ system, the diagram of mechanism was proposed (Fig. 7). 


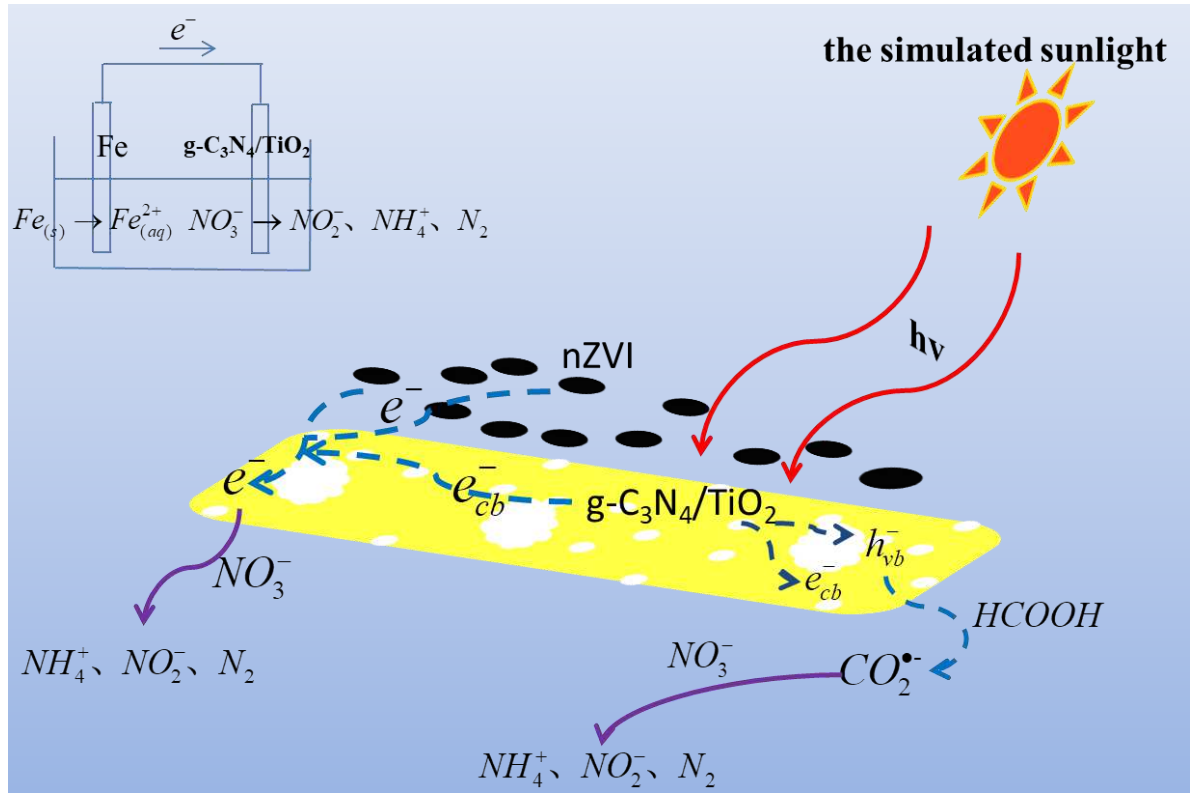

Fig. 7 The Mechanism of Nitrate Reduction in the nZVI-gC $\mathrm{N}_{4} / \mathrm{TiO}_{2} / \mathrm{HCOOH}-\mathrm{Xe}$-lamp System

\section{Conclusion}

The SEM and XRD analysis of nZVI-g- $\mathrm{C}_{3} \mathrm{~N}_{4} / \mathrm{TiO}_{2}$ composite revealed that $\mathrm{g}-\mathrm{C}_{3} \mathrm{~N}_{4} / \mathrm{TiO}_{2}$ effectively could inhibit oxidation and agglomeration of nZVI. Compared with nZVI alone, the rate and efficiency of nitrate removal by nZVI-g- $\mathrm{C}_{3} \mathrm{~N}_{4} / \mathrm{TiO}_{2}$ composite were significantly enhanced. And the experimental results suggested that the $\mathrm{k}$ of $8 \mathrm{~g} / \mathrm{L}$ dosage was 9.8 times higher than of $2 \mathrm{~g} / \mathrm{L}$ dosage. Changing initial $\mathrm{pH}$ affected the product proportion of nitrate reduction. In the acid condition, $\mathrm{NO}_{2}^{-}-\mathrm{N}$ as an intermediate product was accumulated firstly, and then completely reduced to $\mathrm{NH}_{4}^{+}-\mathrm{N}$ or $\mathrm{N}_{2}$. In the alkaline condition, $\mathrm{NO}_{2}^{-}-\mathrm{N}$ concentration increased with time. Adding $\mathrm{HCOOH}$ obviously improved the rate and efficiency of nitrate reduction. In the nZVI-g- $\mathrm{C}_{3} \mathrm{~N}_{4} / \mathrm{TiO}_{2} / \mathrm{HCOOH} / \mathrm{Xe}$-lamp system, nitrate was rapidly reduced due to its synergistic effects of electron from the micro-galvanic cells, the photo-generated electron excited by $\mathrm{g}_{-} \mathrm{C}_{3} \mathrm{~N}_{4} / \mathrm{TiO}_{2}$ under the Xe-lamp and a $\mathrm{CO}_{2}^{--}$species produced by the reaction of $\mathrm{HCOOH}$ and the photo-generated holes excited by $\mathrm{g}-\mathrm{C}_{3} \mathrm{~N}_{4} / \mathrm{TiO}_{2}$ under the Xe-lamp.

\section{Acknowledgements}


This work is supported by the key research and development project of Sichuan Province

(2018GZ0455), the key research and development project of Chengdu City (2019-YF05-00192-SN), and also supported by the High Performance Computing Center of Sichuan Normal University, China.

\section{References}

[1] G. Gulis, M. Czompolyova, J.R. Cerhan, An Ecologic Study of Nitrate in Municipal Drinking Water and Cancer Incidence in Trnava District, Slovakia, Environmental Research 88 (2002).

[2] J. Li, Y. Li, Q. Meng, Removal of nitrate by zero-valent iron and pillared bentonite, J Hazard Mater 174 (2010) 188-193.

[3] L. Dong, L. Lin, Q. Li, Z. Huang, X. Tang, M. Wu, C. Li, X. Cao, M. Scholz, Enhanced nitrate-nitrogen removal by modified attapulgite-supported nanoscale zero-valent iron treating simulated groundwater, J Environ Manage 213 (2018) 151-158.

[4] A. Shukla, J.V. Pande, A. Bansiwal, P. Osiceanu, R.B. Biniwale, Catalytic Hydrogenation of Aqueous Phase Nitrate Over Fe/C Catalysts, Catalysis Letters 131 (2009) 451-457.

[5] D. Zhang, B. Wang, X. Gong, Z. Yang, Y. Liu, Selective reduction of nitrate to nitrogen gas by novel Cu2O-Cu0@Fe0 composite combined with $\mathrm{HCOOH}$ under UV radiation, Chemical Engineering Journal 359 (2019) 1195-1204.

[6] N. Krasae, K. Wantala, Enhanced nitrogen selectivity for nitrate reduction on $\mathrm{Cu}-n Z \mathrm{VI}$ by $\mathrm{TiO}_{2}$ photocatalysts under UV irradiation, Applied Surface Science 380 (2016) 309-317.

[7] J. Ghanei Ardekani, Z. Hassani, Study of the environmental impacts of nitrate pollution and its removal by nanoscale zero-valent iron (NZVI) at the south of Shahre-Kord aquifer (Chaharmahal and Bakhtiari province, Iran), Arabian Journal of Geosciences 11 (2018).

[8] H.J. Lu, J.K. Wang, S. Ferguson, T. Wang, Y. Bao, H.X. Hao, Mechanism, synthesis and modification of nano zerovalent iron in water treatment, Nanoscale 8 (2016) 9962-9975.

[9] S.-S. Chen, H.-D. Hsu, C.-W. Li, A new method to produce nanoscale iron for nitrate removal, Journal of Nanoparticle Research 6 (2005) 639-647.

[10] W. Wang, Z.H. Jin, T.L. Li, H. Zhang, S. Gao, Preparation of spherical iron nanoclusters in ethanol-water solution for nitrate removal, Chemosphere 65 (2006) 1396-1404.

[11] H. Zhang, Z.-h. Jin, L. Han, C.-h. Qin, Synthesis of nanoscale zero-valent iron supported on exfoliated graphite for removal of nitrate, Transactions of Nonferrous Metals Society of China 16 (2006) s345-s349.

[12] J. Luo, G. Song, J. Liu, G. Qian, Z.P. Xu, Mechanism of enhanced nitrate reduction via micro-electrolysis at the powdered zero-valent iron/activated carbon interface, J Colloid Interface Sci 435 (2014) 21-25.

[13] S. Pu, D. Deng, K. Wang, M. Wang, Y. Zhang, L. Shangguan, W. Chu, Optimizing the removal of nitrate from aqueous solutions via reduced graphite oxide-supported $n Z \mathrm{VI}$ : synthesis, characterization, kinetics, and reduction mechanism, Environ Sci Pollut Res Int 26 (2019) 3932-3945. 
[14] H.B. Liu, T.H. Chen, D.Y. Chang, D. Chen, Y. Liu, H.P. He, P. Yuan, R. Frost, Nitrate reduction over nanoscale zero-valent iron prepared by hydrogen reduction of goethite, Materials Chemistry and Physics 133 (2012) 205-211.

[15] Y. Yun, Z. Li, Y.-H. Chen, M. Saino, S. Cheng, L. Zheng, Elimination of nitrate in secondary effluent of wastewater treatment plants by $\mathrm{Fe}^{0}$ and $\mathrm{Pd}-\mathrm{Cu}$ /diatomite, Journal of Water Reuse and Desalination 8 (2018) 29-37.

[16] Z. Shen, X. Dong, J. Shi, Y. Ma, D. Liu, J. Fan, Simultaneous removal of nitrate/phosphate with bimetallic nanoparticles of Fe coupled with copper or nickel supported on chelating resin, Environ Sci Pollut Res Int 26 (2019) 16568-16576.

[17] J. Shi, C. Long, A. Li, Selective reduction of nitrate into nitrogen using Fe-Pd bimetallic nanoparticle supported on chelating resin at near-neutral pH, Chemical Engineering Journal 286 (2016) 408-415.

[18] S.M. Hosseini, T. Tosco, Integrating NZVI and carbon substrates in a non-pumping reactive wells array for the remediation of a nitrate contaminated aquifer, J Contam Hydrol 179 (2015) 182-195.

[19] A.M.E. Khalil, O. Eljamal, T.W.M. Amen, Y. Sugihara, N. Matsunaga, Optimized nano-scale zero-valent iron supported on treated activated carbon for enhanced nitrate and phosphate removal from water, Chemical Engineering Journal 309 (2017) 349-365.

[20] P. Li, K. Lin, Z. Fang, K. Wang, Enhanced nitrate removal by novel bimetallic Fe/Ni nanoparticles supported on biochar, Journal of Cleaner Production 151 (2017) 21-33.

[21] M. Anbia, L. Kamel, Preparation of Pyramids Structured Silicon as a Support for Nano Sized Zero Valent Iron Particles for Nitrate Removal from Water, Silicon 10 (2018) 1851-1859.

[22] M.A. Salam, O. Fageeh, S.A. Al-Thabaiti, A.Y. Obaid, Removal of nitrate ions from aqueous solution using zero-valent iron nanoparticles supported on high surface area nanographenes, Journal of Molecular Liquids 212 (2015) 708-715.

[23] J. Fu, J. Yu, C. Jiang, B. Cheng, g- $\mathrm{C}_{3} \mathrm{~N}_{4}$-Based Heterostructured Photocatalysts, Advanced Energy Materials 8 (2018).

[24] H. Wang, Y. Su, H. Zhao, H. Yu, S. Chen, Y. Zhang, X. Quan, Photocatalytic oxidation of aqueous ammonia using atomic single layer graphitic-C3N4, Environ Sci Technol 48 (2014) 11984-11990.

[25] J. Zhao, N. Li, R. Yu, Z. Zhao, J. Nan, Magnetic field enhanced denitrification in nitrate and ammonia contaminated water under $3 \mathrm{D} / 2 \mathrm{D} \mathrm{Mn} \mathrm{M}_{3} / \mathrm{g}-\mathrm{C}_{3} \mathrm{~N}_{4}$ photocatalysis, Chemical Engineering Journal 349 (2018) 530-538.

[26] J.R. Pan, C. Huang, W.-P. Hsieh, B.-J. Wu, Reductive catalysis of novel $\mathrm{TiO}_{2} / \mathrm{Fe}^{0}$ composite under UV irradiation for nitrate removal from aqueous solution, Separation and Purification Technology 84 (2012) 52-55.

[27] H. Adamu, A.J. McCue, R.S.F. Taylor, H.G. Manyar, J.A. Anderson, Simultaneous photocatalytic removal of nitrate and oxalic acid over $\mathrm{Cu}_{2} \mathrm{O} / \mathrm{TiO}_{2}$ and $\mathrm{Cu}_{2} \mathrm{O} / \mathrm{TiO}_{2}-\mathrm{AC}$ composites, Applied Catalysis $\mathrm{B}$ : Environmental 217 (2017) 181-191.

[28] L. Zhou, L. Wang, J. Zhang, J. Lei, Y. Liu, The preparation, and applications of g- $\mathrm{C}_{3} \mathrm{~N}_{4} / \mathrm{TiO}_{2}$ heterojunction catalysts-a review, Research on Chemical Intermediates 43 (2016) 2081-2101.

[29] J. Lei, Y. Chen, L. Wang, Y. Liu, J. Zhang, Highly condensed g- $\mathrm{C}_{3} \mathrm{~N}_{4}$-modified $\mathrm{TiO}_{2}$ catalysts with enhanced photodegradation performance toward acid orange 7, Journal of Materials Science 50 (2015) 3467-3476. 
[30] W. Wang, J. Fang, S. Shao, M. Lai, C. Lu, Compact and uniform $\mathrm{TiO}_{2} @ g-\mathrm{C}_{3} \mathrm{~N}_{4}$ core-shell quantum heterojunction for photocatalytic degradation of tetracycline antibiotics, Applied Catalysis B: Environmental 217 (2017) 57-64.

[31] B. Lv, X. Feng, L. Lu, L. Xia, Y. Yang, X. Wang, X. Zou, H. Wang, F. Zhang, Facile synthesis of g- $\mathrm{C}_{3} \mathrm{~N}_{4} / \mathrm{TiO}_{2} / \mathrm{CQDs} / \mathrm{Au}$ Z-scheme heterojunction composites for solar-driven efficient photocatalytic hydrogen, Diamond and Related Materials 111 (2021).

[32] B. Zhou, H. Hong, H. Zhang, S. Yu, H. Tian, Heterostructured Ag/g- $\mathrm{C}_{3} \mathrm{~N}_{4} / \mathrm{TiO}_{2}$ with enhanced visible light photocatalytic performances, Journal of Chemical Technology \& Biotechnology 94 (2019) 3806-3814.

[33] R. Geng, J. Yin, J. Zhou, T. Jiao, Y. Feng, L. Zhang, Y. Chen, Z. Bai, Q. Peng, In Situ Construction of $\mathrm{Ag} / \mathrm{TiO}_{2} / \mathrm{g}-\mathrm{C}_{3} \mathrm{~N}_{4}$ Heterojunction Nanocomposite Based on Hierarchical Co-Assembly with Sustainable Hydrogen Evolution, Nanomaterials 10 (2019).

[34] T. Yu, L. Liu, L. Li, F. Yang, A self-biased fuel cell with $\mathrm{TiO}_{2} / g-\mathrm{C}_{3} \mathrm{~N}_{4}$ anode catalyzed alkaline pollutant degradation with light and without light-What is the degradation mechanism?, Electrochimica Acta 210 (2016) 122-129.

[35] Z. Shi, J.T. Nurmi, P.G. Tratnyek, Effects of nano zero-valent iron on oxidation-reduction potential, Environ Sci Technol 45 (2011) 1586-1592.

[36] Y. Liu, J. Lee, Y. Zhao, M. Zhang, L. Wang, Q. Duan, A novel preparation approach and denitrification performance of $\mathrm{TiO}_{2} / \mathrm{Fe}^{0}$ photocatalysts, Desalination and Water Treatment 57 (2014) 3125-3131.

[37] G. Vilardi, L. Di Palma, Kinetic Study of Nitrate Removal from Aqueous Solutions Using Copper-Coated Iron Nanoparticles, Bull Environ Contam Toxicol 98 (2017) 359-365.

[38] A.M.E. Khalil, O. Eljamal, S. Jribi, N. Matsunaga, Promoting nitrate reduction kinetics by nanoscale zero valent iron in water via copper salt addition, Chemical Engineering Journal 287 (2016) 367-380. [39] M.A. Alcudia-Ramos, M.O. Fuentez-Torres, F. Ortiz-Chi, C.G. Espinosa-González, N. Hernández Como, D.S. García-Zaleta, M.K. Kesarla, J.G. Torres-Torres, V. Collins-Martínez, S. Godavarthi, Fabrication of g- $\mathrm{C}_{3} \mathrm{~N}_{4} / \mathrm{TiO}_{2}$ heterojunction composite for enhanced photocatalytic hydrogen production, Ceramics International 46 (2020) 38-45.

[40] M.Z. Kassaee, E. Motamedi, A. Mikhak, R. Rahnemaie, Nitrate removal from water using iron nanoparticles produced by arc discharge vs. reduction, Chemical Engineering Journal 166 (2011) 490-495.

[41] Y. Xi, M. Megharaj, R. Naidu, Dispersion of zerovalent iron nanoparticles onto bentonites and use of these catalysts for orange II decolourisation, Applied Clay Science 53 (2011) 716-722.

[42] C.A.A.e.a. Jacinto Sa' a, Silvia Gross b, James A. Anderson a, *, Photocatalytic nitrate reduction over metal modified $\mathrm{TiO}_{2}$, Applied Catalysis B: Environmental 85 (2009) 192-200. 
Figures

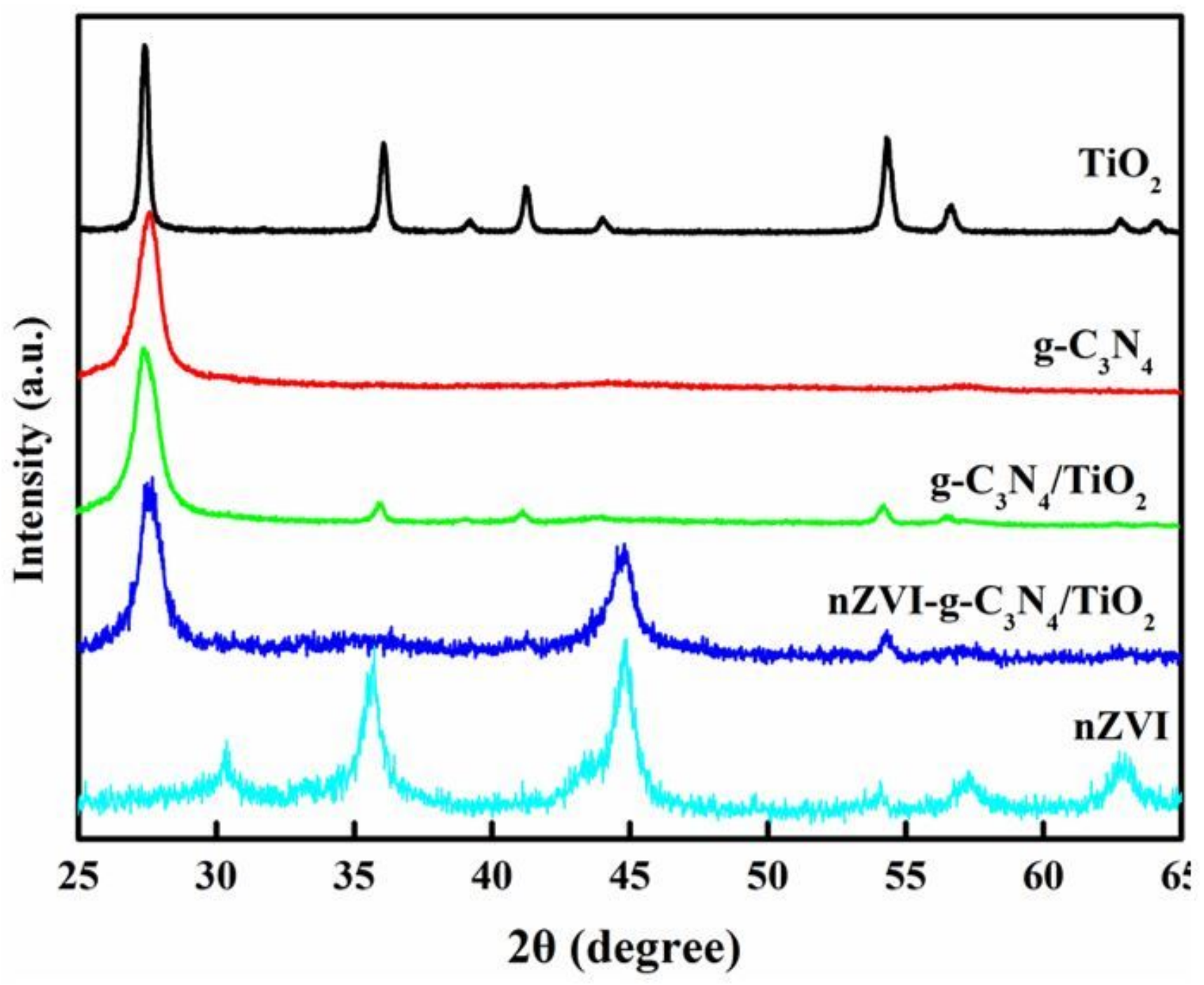

Figure 1

XRD patterns of nZVI, TiO2, g-C3N4, g-C3N4/TiO2 and nZVI-g-C3N4/TiO2 composite. 

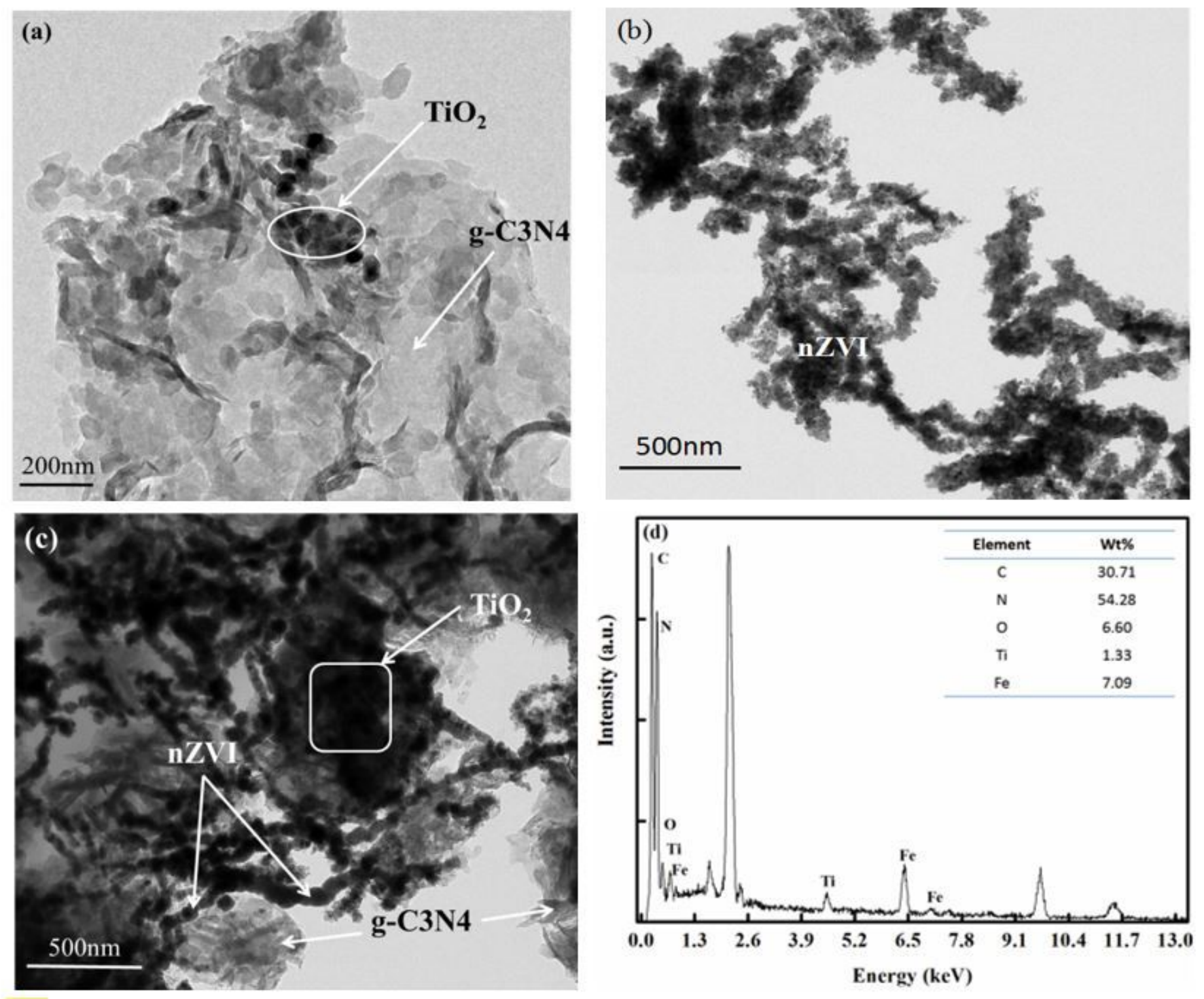

Figure 2

TEM images for (a) the g-C3N4/TiO2; (b) the nZVl; (c) the nZVI-g-C3N4/TiO2 composite; (d) EDS spectrum of the nZVI-g-C3N4/TiO2; 

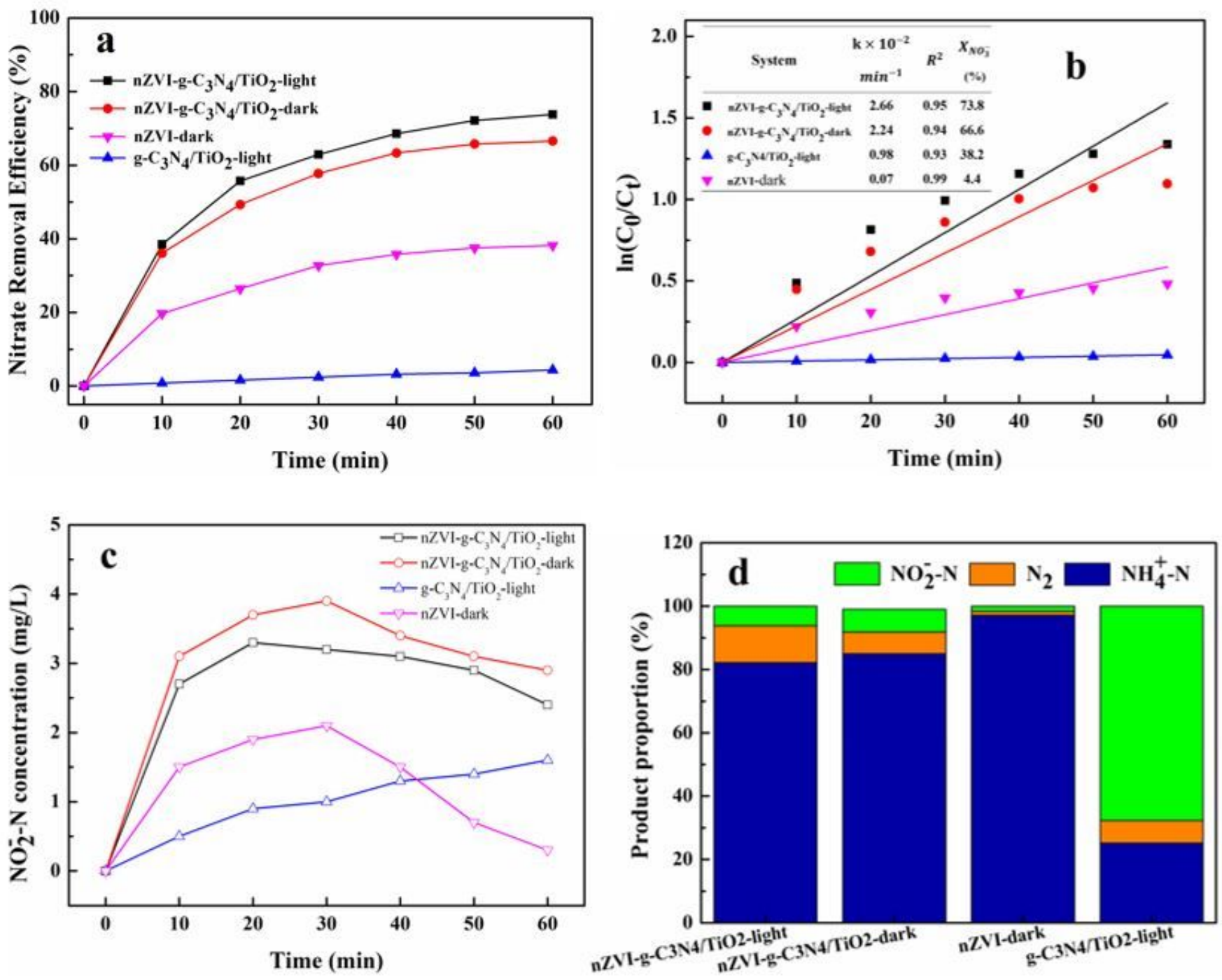

Figure 3

(a) Nitrate removal efficiency of nZVl, g-C3N4/TiO2 and nZVI-g-C3N4/TiO2 composites; (b) Rate constant of nitrate reduction in the different system; (c) nitrite nitrogen concentration $(\mathrm{mg} / \mathrm{L})$ changes during nitrate reduction; (d) Product proportion of nitrate reduction in the different system; (initial nitrate nitrogen concentration at $50 \mathrm{mg} / \mathrm{L}$; reductant dose at $4 \mathrm{~g} / \mathrm{L}$ and initial $\mathrm{pH}$ at 7.0) 

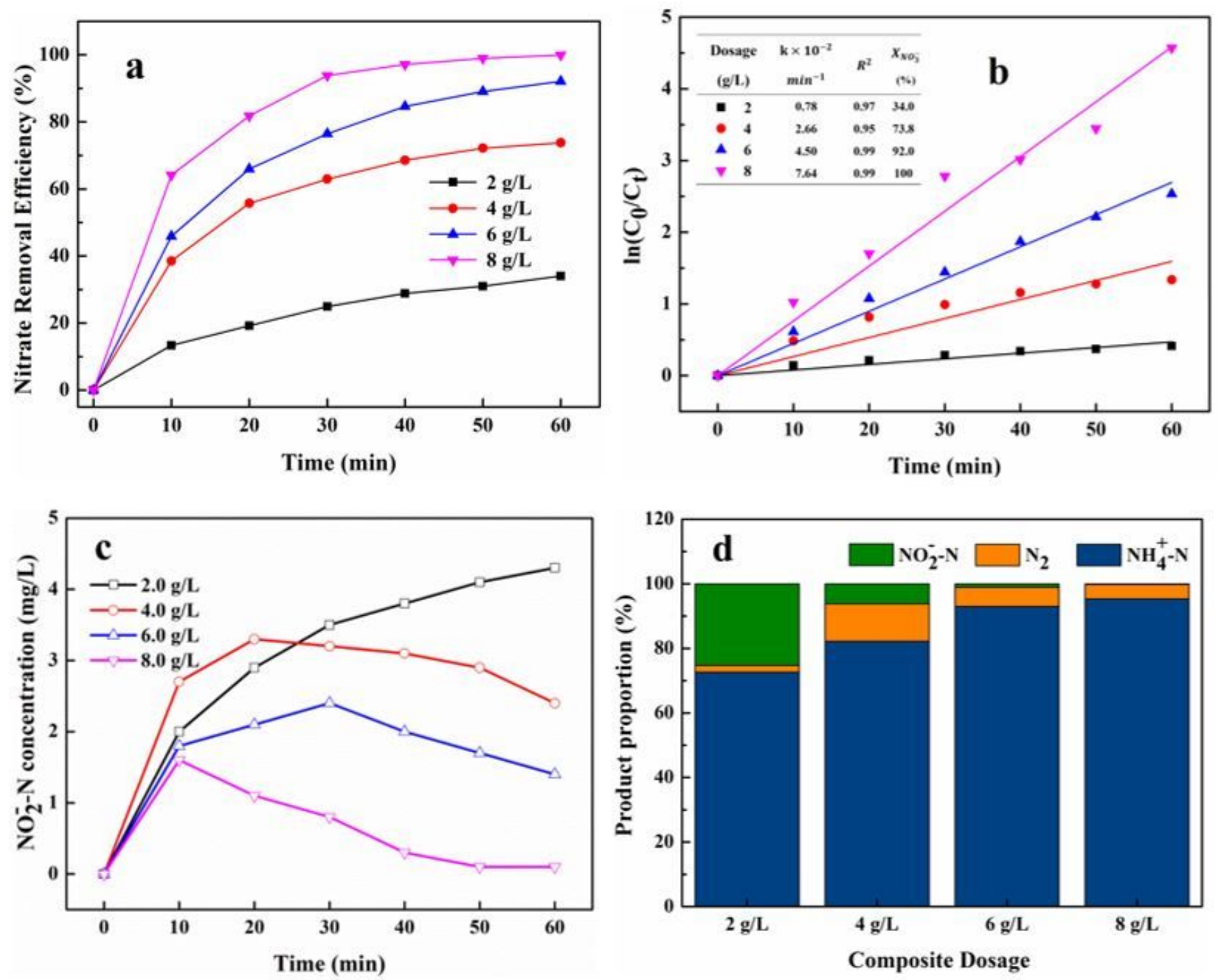

Figure 4

(a) Nitrate removal efficiency in the different nZVI-g-C3N4/TiO2 composite dosage;(b) Rate constant of nitrate reduction in the different composite dosage; (c) nitrite nitrogen concentration ( $\mathrm{mg} / \mathrm{L}$ ) changes during nitrate reduction; (d) Product proportion of nitrate reduction in the different composite dosage; ( initial nitrate nitrogen concentration at $50 \mathrm{mg} / \mathrm{L}$; initial $\mathrm{pH}$ at 7.0 ) 

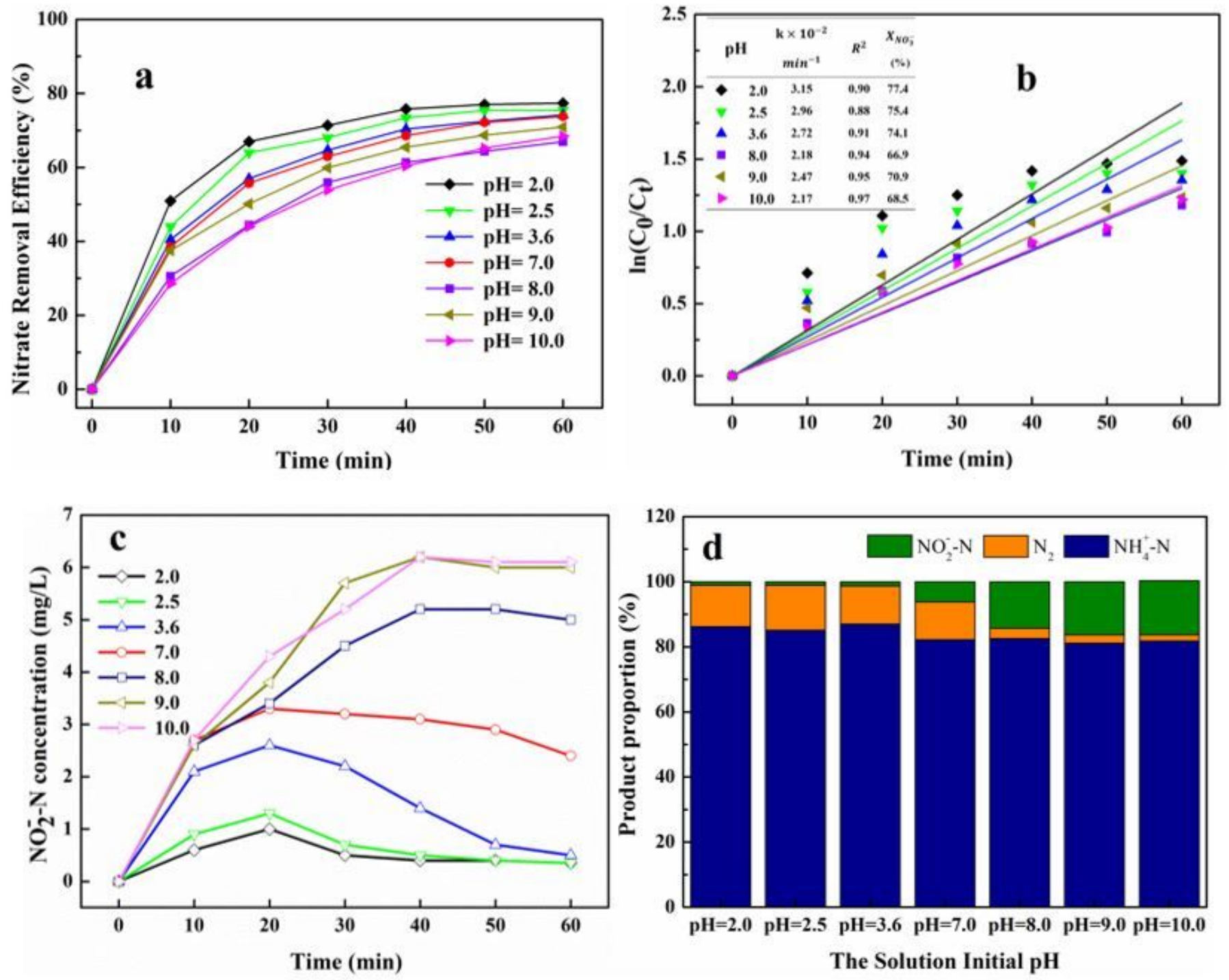

Figure 5

(a) Nitrate removal efficiency in the different solution initial $\mathrm{pH}$; (b) Rate constant of nitrate reduction in the different Initial $\mathrm{pH}$ of solution; (c) nitrite nitrogen concentration $(\mathrm{mg} / \mathrm{L}$ ) changes during nitrate reduction; (d) Product proportion of nitrate reduction in the different Initial pH of solution; ( initial nitrate nitrogen concentration at $50 \mathrm{mg} / \mathrm{L}$; reductant dose at $4 \mathrm{~g} / \mathrm{L}$ ) 

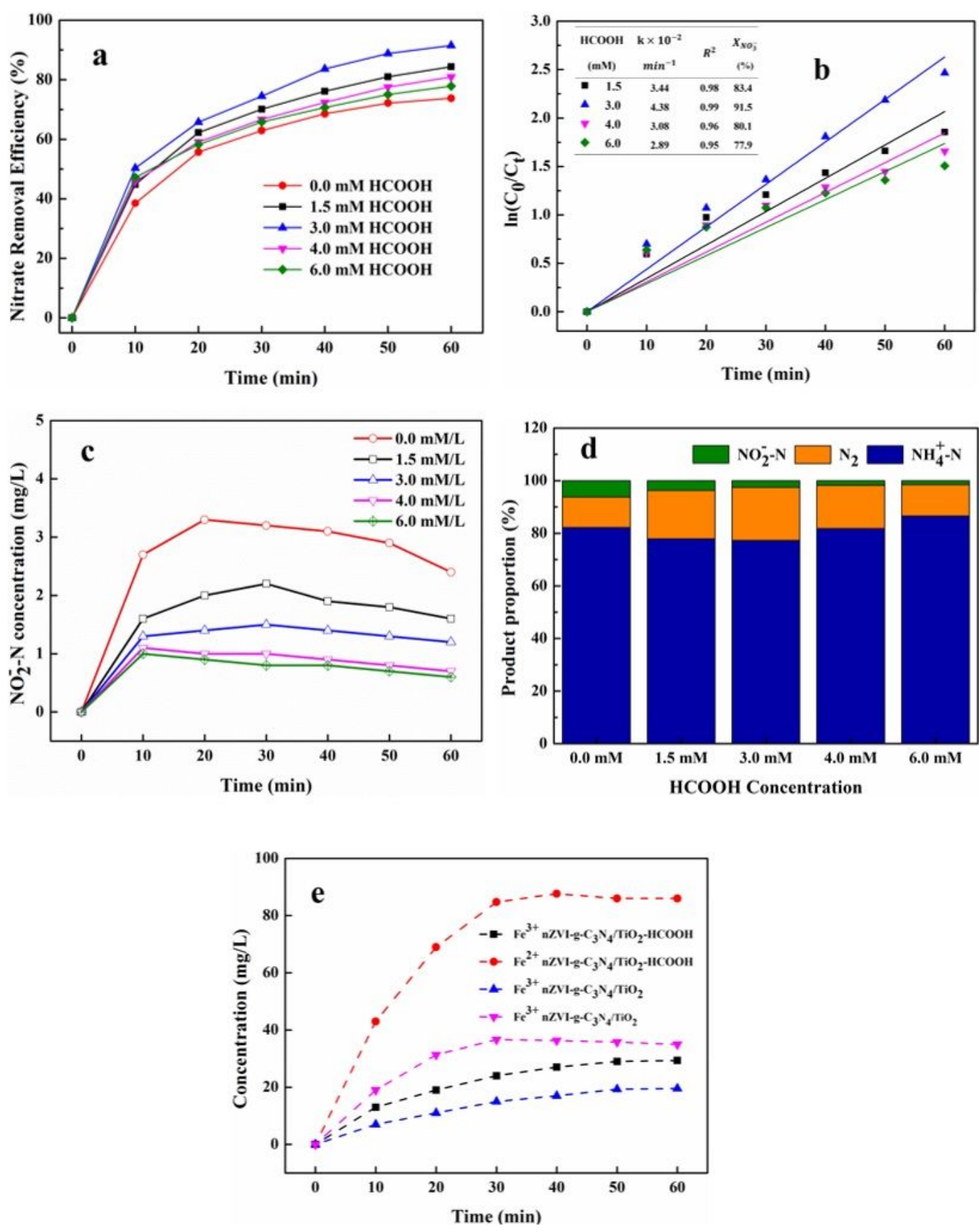

Figure 6

(a) Nitrate removal efficiency in the different $\mathrm{HCOOH}$ concentration; (b) Rate constant of nitrate reduction in the different Initial $\mathrm{pH}$ of solution; (c) nitrite nitrogen concentration $(\mathrm{mg} / \mathrm{L})$ changes during nitrate reduction; (d) Product proportion of nitrate reduction in the different Initial pH of solution; (e) and the concentration of $\mathrm{Fe} 2+$ and $\mathrm{Fe} 3+$ with time; ( initial nitrate nitrogen concentration at $50 \mathrm{mg} / \mathrm{L}$; reductant dose at $4 \mathrm{~g} / \mathrm{L}$ ) 


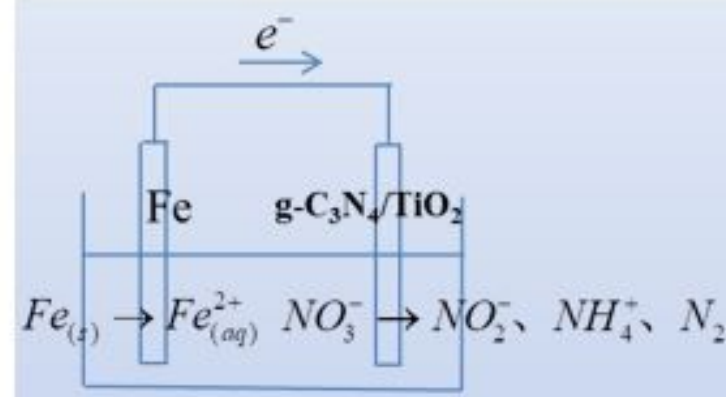

\section{the simulated sunlight}

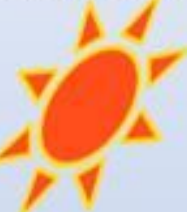

$\mathrm{Fe}_{(\mathrm{p})} \rightarrow \mathrm{Fe}_{(\mathrm{qq})}^{2 \mathrm{~N}} \mathrm{NO}_{3} \rightarrow \mathrm{NO}_{2} 、 \mathrm{NH}_{4} 、 \mathrm{~N}_{2}$

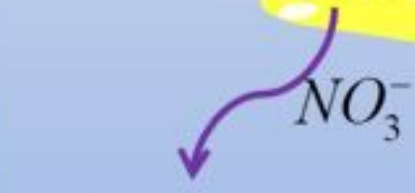

$\mathrm{NH}_{4}^{+} 、 \mathrm{NO}_{2}^{-} 、 \mathrm{~N}_{2}$

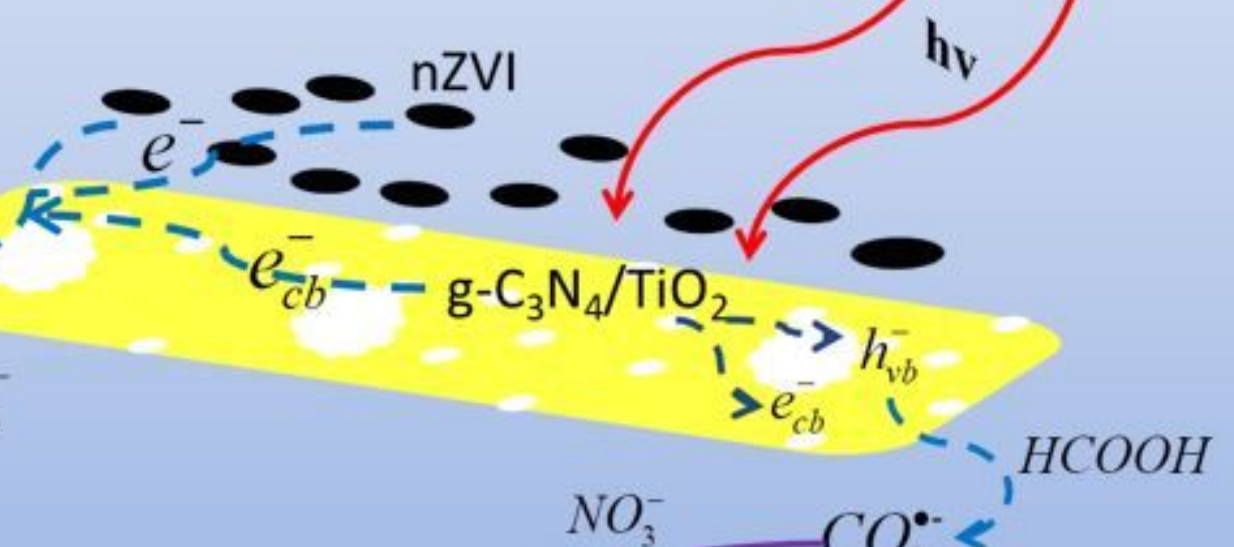

$\mathrm{NH}_{4}^{+} 、 \mathrm{NO}_{2}^{-} 、 \mathrm{~N}_{2}$

\section{Figure 7}

The Mechanism of Nitrate Reduction in the nZVI-gC3N4/TiO2/HCOOH-Xe-lamp System

\section{Supplementary Files}

This is a list of supplementary files associated with this preprint. Click to download.

- supportinformationFigure.docx 